\title{
PRIVILEGIOS PROCESALES INCONSTITUCIONALES E INNECESARIOS EN LA ESPAÑA DEMOCRÁTICA DEL SIGLO XXI: EL SORPRENDENTE MANTENIMIENTO DE LA INSTITUCIÓN DEL AFORAMIENTO
}

\author{
JUAN-LUIS GÓMEZ COLOMER \\ Catedrático de Derecho Procesal \\ Universidad Jaume I de Castellón
}

\section{SUMARIO}

I. Una nueva conciencia social sobre los abusos de una injustificada protección procesal penal del Poder en la España actual. II. Las exorbitantes ramificaciones de tan desmesurado privilegio político-jurídico. III. La desigualdad sobre la desigualdad, dos ejemplos clamorosos. IV. El análisis jurídico del aforamiento: Una clara vulneración del principio constitucional de igualdad. V. Conclusiones al hilo de las anunciadas reformas: Escepticismo sin matices.

\section{UNA NUEVA CONCIENCIA SOCIAL SOBRE LOS ABUSOS DE UNA INJUSTIFICADA PROTECCIÓN PROCESAL PENAL DEL PODER EN LA ESPAÑA ACTUAL.}

España es un país que contempla numerosísimos privilegios procesales penales en su ordenamiento jurídico ${ }^{1}$. Si nos fijamos tan sólo en los aforamientos, es decir en las reglas de competencia procesal penal en virtud de las cuales se atribuye competencia objetiva y funcional a tribunales penales superiores a los fijados para los casos usuales cuando se enjuicia a un alto cargo, autoridad o funcionario público de cualquier poder del estado, y dentro de ellos en los que tienen origen político, podríamos estar hablando de más de 2.000 posibilidades, si añadimos otros campos como el judicial o fiscal, podríamos llegar a más 10.000, y si contamos a los miembros de las fuerzas y cuerpos de seguridad, que son unos

1 Véase Montero Aroca, J., Los privilegios en el proceso penal, en Gutiérrez-Alviz Conradi, F. (coord.), «La criminalidad organizada ante la Justicia», Ed. Universidad, Sevilla 1996, pp. 107 y ss. 
250.000 y que también están aforados, la cifra es realmente escandalosa. Eso es, sencillamente, un auténtico despropósito, que no ocurre en ningún país de nuestro entorno cultural y jurídico, como se irá comprobando a lo largo del presente artículo $^{2}$.

Digamos ahora, sin perjuicio de mayores precisiones más tarde, que su existencia se quiere justificar, aunque hay demasiada protección y el aforamiento es el culpable de ello, porque las elevadas funciones políticas o jurídicas que cumplen quienes están protegidos por la inmunidad no pueden quedar a merced del capricho o irresponsabilidad de los ciudadanos, sobre todo de sus „,venganzas políticas «, por lo que es necesaria una protección especial de su función, dada la amplitud que ofrece el art. 24.1 CE. En suma, se supone que a mayor calidad del órgano, mejor enjuiciamiento ante lo delicado de la cuestión, por lo que de alguna manera también el aforamiento favorece al Poder Judicial. El aforamiento se incardina por tanto en la determinación de la competencia procesal penal.

El ejemplo de privilegio puesto, el aforamiento, no se entiende sin la regulación que el Derecho sustantivo (Derecho Constitucional y Derecho Penal) hace de la inviolabilidad y la inmunidad parlamentarias ${ }^{3}$, conceptos de referencia necesarios aunque no únicos ${ }^{4}$.

En efecto, en España se afirma que la inmunidad en sentido genérico comprende tanto la inviolabilidad como la inmunidad, dos institutos que tienen la misma naturaleza y el mismo fundamento jurídico, basados ambos en el Derecho Parlamentario. La inviolabilidad y la inmunidad parlamentarias son privilegios de determinadas instituciones públicas y de ciertos altos cargos, autoridades y

2 He tratado ampliamente el aforamiento en: Gómez Colomer, J.L. / Esparza Leibar, I., Tratado jurisprudencial de aforamientos procesales, Ed. Tirant lo Blanch, Valencia 2009, passim. En este libro analizamos todas las cuestiones aquí consideradas, por lo que no haremos más referencia al mismo. Por supuesto, hemos actualizado su contenido doctrinal y jurisprudencialmente a efectos de la publicación de este escrito.

3 Tampoco se comprenden éstas sin un estudio histórico para saber por qué nacen y cómo se desarrollan (básicamente del Derecho consuetudinario inglés y del Derecho francés post-revolucionario). Véanse FeRNÁNdeZ-Miranda y Campoamor, A., Artículo 71. Inviolabilidad e inmunidad parlamentarias, en Alzaga Villaamil, O. (Dir.), «Comentarios a las Leyes Políticas. Constitución española de 1978», Edersa, Madrid 1989, vol. VI, p. 375. Obviamente, la doctrina constitucional y penal, e incluso la administrativa, se ha ocupado de este tema en mayor o menor medida y en función de su especialidad. No haremos más citas sin embargo de ella, sino sólo exclusivamente de la doctrina procesal, dogmática o pragmática, teórica o práctica. En el libro citado en la nota anterior tiene recogida el lector interesado la bibliografía más importante de esas especialidades jurídicas, al que por ello me remito.

4 No debe olvidarse que en España el privilegio procesal del aforamiento debe relacionarse también con la supresión de los fueros en 1868, pues aunque el Real Decreto-ley de 6 de diciembre de 1868 organizó de manera moderna y adecuada para la época los tribunales de justicia y su competencia objetiva, los sujetos a las jurisdicciones especiales cuya supresión estaba afectada por la norma bregaron hasta el final por conservar sus privilegios, especialmente por la calidad del órgano enjuiciador, lo que influyó directamente en la expansión del aforamiento. Un resumen puede consultarse en Crónica de la Codificación Española, tomo 1 Organización Judicial, Ministerio de Justicia y Comisión General de Codificación, Madrid 1970, p. 96. Véase también GóMEZ Colomer, J.L., Altos funcionarios y protección procesal penal (un intento de aclaración), «Estudios Jurídicos Ministerio Fiscal», Centro de Estudios Jurídicos de la Administración de Justicia, Madrid 1998, pp. 327 y ss. 
funcionarios públicos, electos o no, por tanto, de carácter objetivo y subjetivo, que impiden el desarrollo normal del proceso penal en algunos casos.

En este sentido, la inviolabilidad protege la libertad de expresión del parlamentario o beneficiado por ella mientras esté en el cargo, impidiendo cualquier actuación procesal penal en su contra por las opiniones manifestadas en el ejercicio de sus funciones. Mientras que la inmunidad, entendida en sentido estricto, a diferencia de la inviolabilidad, sólo implica la imposibilidad de persecución penal durante el período en que la alta autoridad, el alto funcionario o el alto cargo ocupen el puesto público, por delito cometido que tenga que ver con el ejercicio de las funciones propias, salvo que la cámara tratándose de parlamentarios lo autorice expresamente.

La protección privilegiada se establece por nuestra Constitución en varios lugares, pero no es el único texto legal, pues numerosas normas toman como modelo las disposiciones constitucionales para desarrollar y establecer nuevas y variadas protecciones:

1. La Constitución española regula en efecto la inviolabilidad e irresponsabilidad del Rey (arts. 56.3 y 62.4), la inviolabilidad de Diputados y Senadores (art. 71.1), su inmunidad y aforamiento (art. 71.2 y 3), y la responsabilidad penal del Presidente del Gobierno y de los Ministros (art. 102).

2. Muchas leyes de rango inferior, básicamente de carácter orgánico, establecen privilegios procesales para altos cargos, autoridades y funcionarios públicos distintos a los citados. Me limitaré a una enumeración subjetiva:Parlamentarios autonómicos, magistrados del Tribunal Constitucional, magistrados y jueces del Poder Judicial ordinario, fiscales, defensor del pueblo estatal y autonómicos, y policías (miembros de la policía nacional, guardia civil, policía autonómica y policía local). Todos ellos están aforados en España a un tribunal superior al que sería en principio su juez ordinario predeterminado por la ley.

3. También es amplio el listado de privilegios procesales de determinados extranjeros cualificados que delincan en España: Embajadores, cónsules, magistrados de tribunales internacionales y supranacionales, defensores del pueblo, miembros de fuerzas de paz, etc.

Pues bien, el aforamiento procesal penal es consecuencia de la inmunidad constitucional, ya que es predicable de todas las personas inmunes. Significa una alteración de las reglas de la competencia objetiva, funcional y territorial, en virtud de la cual un tribunal fijado legalmente y sólo él es competente para enjuiciar a personas que gozan de inmunidad, que se configura además como un derecho del imputado (investigado, encausado) a ser sometido exactamente ante ese juzgado o tribunal y a ser enjuiciado sólo por él.

La doctrina española entiende que el aforamiento no vulnera el principio del juez legal, pues todas las normas en que se contiene nos dicen previamente ante 
qué tribunal causa efecto esta protección de la inmunidad ${ }^{5}$. Por eso, juez legal para enjuiciar a un diputado es el Tribunal Supremo, por eso juez legal para enjuiciar a un presidente autonómico es el Tribunal Superior de Justicia de su comunidad autónoma, y así ha sido reconocido por nuestra jurisprudencia sin excepción ${ }^{6}$.Pero ese principio constitucional y al mismo tiempo derecho fundamental del acusado no es precisamente el que está en juego aquí de manera terminante. Además, ha habido un cambio importante en la interpretación del principio del juez legal respecto a aforados ante el Tribunal Supremo, que ha variado toda una doctrina clásica, como veremos con detalle en el apartado III, B) infra.

Todo ello sumado implica como resultado final que en España haya como dijimos más de 250.000 aforados, algo inadmisible desde el punto de vista constitucional y también social, como intentaré demostrar en las páginas que siguen (v. apartado IV).

\section{LAS EXORBITANTES RAMIFICACIONES DE TAN DESMESURADO PRIVILEGIO POLÍTICO-JURÍDICO}

Nos vamos a referir exclusivamente en las páginas siguientes a los llamados aforamientos políticos: El Jefe del Estado, el Presidente del Gobierno, Los Ministros del Gobierno, los Diputados y Senadores del Estado, y los diputados autonómicos, por ser los de mayor trascendencia pública.

\section{La irresponsabilidad del Jefe del Estado}

Se ha dicho desde siempre que el Rey de España en cuanto Jefe del Estado es constitucionalmente inviolable e irresponsable (arts. 56.3 y 64.2 CE), tanto en lo político como en lo jurídico, lo que significa que no puede cometer ningún ilícito (por aplicación del principio princeps legibus solutus est; en versión moderna del constitucionalismo inglés the king can do not wrong). Al ser refrendados sus actos por el Presidente del Gobierno o sus ministros, ellos serían los responsables administrativos y penales de los mismos.

5 Véase sobre este principio Montero Aroca, J., en Montero Aroca, J. / Gómez Colomer, J.L. / Barona Vilar, S., Derecho Jurisdiccional, t. I (Parte General) (24. ${ }^{a}$ ed.), Tirant lo Blanch, Valencia 2016, pp. 89 a 94.

6 Véanse Montón Redondo, A., Atribuciones de los Tribunales Superiores de Justicia de las Comunides Autónomas, La Ley 1986, t. II, pp. 1218 y ss.; VAlls Gumbau, F., Las competencias penales de los Tribunales Superiores de Justicia; Poder Judicial 1989, n. ${ }^{\circ} 13$, pp. 62 y ss.; Montero Aroca, J., La reforma de las Salas de lo Civil y Penal, Poder Judicial 1991, n. ${ }^{\circ} 24$, pp. 103 y ss.; y Flors Matíes, J., La Sala de lo Civil y Penal del Tribunal Superior de Justicia. Constitución, composición, competencia y especialidades procesales, Revista Valenciana d'Estudis Autonòmics 1997, pp. 195 y ss. 
Este fundamento clásico está sujeto hoy sin embargo a discusión, porque el Derecho Internacional Público ya no está tolerando desde hace unas pocas décadas la impunidad de determinados delitos cometidos por un jefe de estado de cualquier país del mundo. Aunque deberíamos distinguir entre el Rey como Jefe del Estado español, y los demás Jefes de Estado extranjeros, sólo me referiré al primero de los supuestos.

En este sentido, el mantenimiento de una inviolabilidad absoluta no es acorde con la Constitución, ni siquiera para el Jefe del Estado. El Rey puede cometer delito y ser responsable por ello. Ciertamente no estamos pensando en cualquier delito, pero sí en algunos de los más graves. No sería admisible jurídicamente que, si el Jefe del Estado ordenara en España, o fuera copartícipe de una orden dada por el Presidente del Gobierno, por poner un ejemplo tan bárbaro como comprensible, acordando la exterminación de los gitanos (delito de genocidio), fuera declarado irresponsable de ello. Jurídicamente no debería haber problema alguno: Se le destituiría políticamente como Jefe del Estado por ese hecho y se le enjuiciaría criminalmente después (se supone ante la falta de norma que por el Tribunal Supremo).

Este simple ejemplo pone de manifiesto que los delitos contra los derechos humanos cometidos por los jefes de estado no pueden quedar impunes por meras disposiciones internas, aunque tengan rango constitucional. Sólo así se explica que el Tratado por el que se creó la Corte Penal Internacional y se reguló su funcionamiento (Estatuto de Roma de la Corte Penal Internacional, hecho en Roma el 17 de julio de 1998), haya podido ser ratificado por España, pues se contemplan en él los delitos más graves contra la humanidad, que pueden cometer, y de hecho cometen o amparan casi siempre jefes de estado (art. 27).

Esa responsabilidad sería penal, además de costarle constitucionalmente sin duda alguna su derrocamiento, en principio sin necesidad de cambiar la Constitución, aunque sí debe desarrollarse primero el procedimiento mediante una ley orgánica por mandato expreso del art. 57.5CE, lo que no ha sucedido todavía, y siempre que el régimen democrático continuara, lo que lógicamente y en buena lid debemos contemplar. Pero respecto a lo penal, nada hay regulado por ese entendimiento clásico de la inviolabilidad real. En cualquier caso, no puede admitirse que el Jefe del Estado español sea inviolable internamente y no internacionalmente.

\section{La especial protección del Presidente del Gobierno y de los Ministros del Gobierno}

Un caso específico de protección es el previsto para el Presidente y demás miembros del Gobierno por el art. 102.2 CE respecto a dos tipos de hechos delictivos gravísimos para la democracia. Consiste en la fijación de un presupuesto procesal reforzado (condición de procedibilidad), cuando se quieran emprender 
acciones penales contra el Presidente del Gobierno o contra alguno o algunos miembros del Gobierno por comisión de delitos de traición o contra la seguridad del Estado, a saber, que el suplicatorio se otorgue previa «iniciativa de la cuarta parte de los miembros del Congreso, y con la aprobación de la mayoría absoluta del mismo».

Al establecer la Constitución en su art. 102 la responsabilidad penal del «Presidente y los demás miembros del Gobierno», está optando por un sistema judicial de exigencia de responsabilidad penal, que contiene una fase previa parlamentaria en determinados casos. De acuerdo con ello, esta norma fija tres tipos de perseguibilidades, además de un aforamiento específico y la inaplicabilidad del derecho real de gracia, en su caso, a tan altas personalidades.

Las tres posibilidades de persecución penal giran en torno a si son parlamentarios (que es lo usual) o no, y a si el hecho criminal cometido fueran una o las dos clases de hechos punibles extremadamente graves que refleja la norma suprema. No entraremos tampoco, dentro de estas cuestiones, en los requisitos de perseguibilidad que la Constitución establece (el procedimiento a seguir en el Parlamento español, llamado de suplicatorio).

Pero antes de tratar la persecución de las más altas autoridades políticas del Estado que son responsables jurídicamente, es preciso resolver una pregunta, que no tendría mayor importancia si no se hubiera planteado en al menos una ocasión con especial virulencia, en 1995: ¿Quién forma parte del Gobierno en España?

\section{A) Requisito personal específico}

La Constitución exige un requisito personal concreto: Ser Presidente del Gobierno o ser miembro del Gobierno. En efecto, para que el artículo $102 \mathrm{CE}$ sea aplicable, es preciso ser o Presidente del Gobierno, o miembro del Gobierno, que son, además del Presidente, de los Vicepresidentes si los hubiera, y de los Ministros, «los demás miembros que establezca la Ley» (art. $98 \mathrm{CE}$ ).

Los problemas se han planteado respecto a la frase que hemos marcado entre comillas. Quiere esto decir que en España sólo se ha discutido, y en verdad sólo en una ocasión si no recordamos mal, con relación no al Presidente del Gobierno, o a sus Vicepresidentes o a sus Ministros, sino respecto a los demás miembros que establezca la ley.

La doctrina constitucionalista ha llegado a la conclusión, después de unos años de discusión, que los demás miembros del Gobierno hoy son ninguno, es decir, no existen, porque la Ley 50/1997, de 27 de noviembre, del Gobierno (no afectada en este punto por la reforma operada por la Ley 40/2015, de 1 de octubre, de Régimen Jurídico del Sector Público), no ha incluído a ningún miembro más. Por tanto, el Gobierno está formado sólo por su Presidente, los Vicepresidentes si los hubiere, y los Ministros, lo que significa que todos los demás posibles altos cargos están excluídos, especialmente los Secretarios de Estado. 
Pues bien, resuelta la anterior pregunta, entremos ya en lo que el contenido del art. 102.2 CE afecta al Derecho Penal sustantivo. Ante todo, debe decirse que lo que pretende la $\mathrm{CE}$ al reflejar delitos cometidos en el ejercicio de sus funciones por el Presidente del Gobierno o sus Ministros, son delitos gubernativos o ministeriales, que como tal no tienen ajuste terminológico con el Código Penal, pero que resultan de una gran plasticidad a la hora de identificarlos. Se trata de dos grupos de hechos punibles: Los delitos de traición por un lado, y los delitos contra la seguridad del Estado por otro.

\section{B) Perseguibilidad de hechos punibles de traición}

El art. 102.2 CE dispone una regulación expresa para enjuiciar al Presidente del Gobierno y a alguno o algunos de sus Ministros, solos o conjuntamente, si son acusados por «traición», con ocasión de estar cumpliendo con sus obligaciones públicas («en el ejercicio de sus funciones»).

El término «acusación» está empleado incorrectamente, puesto que lo que en realidad quiso decir la Constitución es «imputación», dado que nuestro proceso penal, a diferencia del anglosajón y más concretamente del de los Estados Unidos, tanto el federal como el de los estados, no comienza por una acusación, sino por el inicio formal de la investigación del hecho y de su posible autor que la fundarán posteriormente (arts. 299 y ss. de la Ley de Enjuiciamiento Criminal de 1882).

Dicho ello, la pregunta sustantiva que hay que hacerse es: ¿Qué es delito de traición aplicado a estas altas autoridades y en dónde viene establecido? El Código Penal hoy vigente regula como tales los delitos comprendidos en los arts. 581 a 588, especialmente este último, aplicable a los miembros del Gobierno, que castiga con pena de prisión de 15 a 20 años al Gobierno de la Nación que, sin cumplir con lo dispuesto en la Constitución, declaren la guerra o firmen la paz. En definitiva, traición es hoy para una alta autoridad comprometer en forma inconstitucionalmente ilegítima la integridad territorial y la independencia de España, en grave peligro si hay una guerra de por medio.

El delito de traición no se debería resolver aquí en inducir a la guerra contra España, o en concertarse para ello con una potencia extranjera, como podría desprenderse del art. 581, ya que esas conductas típicas deberían reservarse para los españoles ciudadanos de a pie, sino que debería consistir tan sólo en que el Presidente del Gobierno o sus Ministros realicen la conducta típica de declarar la guerra o la paz sin observancia de las formalidades previstas por la Constitución, porque el tipo configura un delito especial propio reducido a estas altas personalidades. Forma parte de los llamados delitos políticos, aunque debería tratarse más bien de un delito contra la Constitución. En nuestra opinión y coherentemente con ello, por delito de traición incardinable en el art. 102.2 CE solamente cabría hablar hoy de las conductas típicas reguladas en el art. 588 del Código Penal. 


\section{C) Perseguibilidad de hecho punible contra la seguridad del Estado}

El art. 102.2 CE dispone igualmente una regulación expresa, la misma que en el caso anterior, para enjuiciar al Presidente del Gobierno y a alguno o algunos de sus Ministros, solos o conjuntamente, si son acusados por «cualquier delito contra la seguridad del Estado», estando también en el ejercicio de sus funciones.

A diferencia de lo que ocurre con la traición, el Código Penal no regula nominalmente los delitos contra la seguridad del Estado, aunque sí hay preceptos que se refieren a ella directamente, como los arts. 589 y 596.1, dentro de los delitos que comprometen la paz o la independencia del Estado (arts. 589 a 597 del Código Penal), o indirectamente los delitos contra la defensa nacional (arts. 598 a 603 del Código Penal). Por otra parte, en los arts. 472 a 543 se regulan los llamados delitos contra la Constitución, que protegen como bien jurídico el orden constitucional.

La pregunta sustantiva que hay que hacerse es, pues, también: ¿Qué es delito contra la seguridad del Estado? La respuesta es aquí más complicada, pero en general debe decirse que las conductas típicas que el Presidente del Gobierno y sus Ministros realizarían contra la seguridad del Estado, consistirían en atentar contra la independencia o seguridad del Estado, atentar contra los valores constitucionales oponiéndose a la observancia de las leyes que los recogen, o provocando su incumplimiento, así como intentar acabar con el régimen democrático.

Pero en esos preceptos se recogen muchos tipos, la mayor parte de los cuales no son aplicables ni al Presidente del Gobierno, ni a sus Ministros. Afortunadamente, no tenemos ni un sólo caso práctico que citar y del que aprender. Por eso, en suma, de lo que se trataría es de pensar en conductas típicas en las que el Presidente del Gobierno o el Ministro hayan comprometido el orden constitucional que los españoles hemos decidido darnos para regular pacífica y democráticamente nuestra convivencia, lo que implicaría un grave peligro, por ejemplo, si apoyaran o sustentaran un intento de golpe de estado, o buscaran una guerra con su actuación. Delinquir contra la seguridad del Estado debe equivaler por esto mismo a subvertir el orden constitucional, de ahí que el art. 102.2 CE, en este punto, lo que quiere de verdad es establecer un mecanismo especial de defensa de la Constitución.

Aunque la Constitución no diga nada en este precepto, las posibilidades citadas no son las únicas de enjuiciar al Presidente del Gobierno o a algún Ministro del mismo que se deducen de ella. En efecto, dos casos ulteriores existirían fuera de los delitos de traición y contra la seguridad del estado, según sean parlamentarios o no. El art. 102.1 CE, al no distinguir como sí hace su apartado 2, permite llegar a la conclusión de que el Presidente del Gobierno, los Vicepresidentes del Gobierno, y los Ministros del Gobierno pueden cometer delitos distintos a los mencionados. Por ejemplo, de homicidio, de violencia de género, conducción bajo la influencia de bebidas alcohólicas, etc. Pues bien, la importancia del art. 102.1 es que no prevé ninguna condición de procedibilidad como sí hace el apar- 
tado 2 para los delitos de traición y contra la seguridad del Estado explicados antes, limitándose a establecer el fuero de la Sala II del Tribunal Supremo para su enjuiciamiento.

La expresión «en su caso» del art. 102.1CE, si no es un error dogmático, es hoy irrelevante, puesto que el aforamiento concurre siempre, sin excepción alguna, salvo que se refiera a otros delitos distintos de los mencionados en el art. 102.2, supuesto en el que está expresada y ubicada en forma defectuosa gramatical y sistemáticamente. Además, en ninguno de los dos supuestos tiene sentido, porque el único tribunal competente para enjuiciar al Presidente del Gobierno, a los Vicepresidentes y a los Ministros, dado nuestro absurdo sistema de aforamientos, no puede ser otro que la Sala II de lo Penal del Tribunal Supremo, porque el juego de privilegios procesales no toleraría para estos altos cargos, en comparación con los demás, de rango jerárquico inferior, un órgano jurisdiccional de menor categoría procesal, y así lo dispuso expresamente la Ley Orgánica del Poder Judicial de 1985, como citaremos inmediatamente.

Pues bien, en esos casos, que pueden ser perfectamente reales, la solución depende de si el alto cargo es parlamentario, lo que será usual, o no:

1. Perseguibilidad de delitos distintos, pero siendo el Presidente del Gobierno o el Ministro imputado parlamentario: Si es parlamentario, su régimen jurídico será el mismo que si fueran un diputado o un senador del Estado (v. inmediatamente).

2. Perseguibilidad de delitos distintos no siendo el Presidente del Gobierno o el Ministro imputado (investigado) parlamentario: En este caso, puramente hipotético respecto al Presidente del Gobierno, puesto que todos los presidentes de gobierno desde la reinstauración de la democracia en 1978 han sido siempre parlamentarios en España y así debería seguir siendo, aunque no respecto a algunos Ministros, la única cuestión que se plantea es qué tribunal será competente para enjuiciarlos. La respuesta debe ser también la Sala II de lo Penal del Tribunal Supremo, por interpretación sistemática de lo dispuesto en el art. 102 en su conjunto. La Ley Orgánica del Poder Judicial resolvió en 1985 el problema interpretativo estableciendo en estos casos la competencia de la Sala II del Tribunal Supremo tanto para el enjuiciamiento del Presidente del Gobierno como de sus Ministros (art. 57.1-2. ${ }^{\circ}$.

En estos dos últimos subapartados considerados, alguno de los delitos cometidos por el Presidente del Gobierno, por alguno de los Vicepresidentes del Gobierno, o por algún Ministro, que no son ni el de traición ni ninguno de los posibles contra la seguridad del Estado, podría ser competencia del Tribunal del Jurado. Pensemos, por qué no, en un ministro asesino. Los arts. 1.1, a), 1.2, a) y 2, II de la Ley del Jurado de 1995 así lo prevén, pero ni el Fiscal General del Estado ni el propio Tribunal Supremo lo interpretan literalmente, entendiendo 
con argumentos excesivamente formalistas que la Constitución tiene valor superior y por tanto que enjuicia el Tribunal Supremo (como tribunal exclusivamente técnico) y no el Tribunal del Jurado del Tribunal Supremo. El valor superior es indiscutible, pero entonces, ¿para qué se ha incardinado un Tribunal del Jurado en el Tribunal Supremo? Me remito más ampliamente por su importancia sobre esta doctrina contra legem al apartado III infra.

\section{Los privilegios de los parlamentarios}

El art. 71 CE establece la inviolabilidad de los Diputados y Senadores por sus opiniones, así como su inmunidad. Se afirma doctrinalmente que estamos aquí ante la verdadera inviolabilidad y ante la verdadera inmunidad. Por tanto, éste es el supuesto legal que mayor trascendencia tiene en nuestra actual práctica. Su desarrollo procesal penal ordinario se encuentra básicamente en los arts. $750 \mathrm{a}$ 756 de la Ley de Enjuiciamiento Criminal, y en la Ley de 9 de febrero de 1912 de jurisdicción y procedimiento especiales en las causas contra senadores y diputados, preceptos muy anticuados y en parte inconstitucionales, que pretenden configurar una especie de proceso penal especial ${ }^{7}$. En ambos casos es competente la Sala II del Tribunal Supremo para conocer de las causas contra parlamentarios. La inmunidad les protege también frente a la detención y se establece un trámite llamado de suplicatorio o procedimiento de autorización para enjuiciar criminalmente al diputado o senador, que tiene lugar en el seno de la cámara respectiva (Congreso de los Diputados y Senado) ${ }^{8}$.

La inviolabilidad de nuestros diputados y senadores garantiza protección, según el art. 71.1CE, por «las opiniones manifestadas en el ejercicio de sus funciones». La jurisprudencia constitucional extiende el término opinión a los votos emitidos en cumplimiento de sus obligaciones. La cuestión penal inmediata que plantea esta declaración, por tanto, es determinar con exactitud qué delitos pueden cometer nuestros parlamentarios cuya acción típica se contenga en opiniones y votos, es decir, estudiar qué delitos se pueden cometer utilizando la palabra.

Esto es importante porque la inviolabilidad parlamentaria no ofrece protección frente a cualquier actuación delictiva del diputado o senador. El mensaje en este caso parece ser pues que nadie está por encima de la ley, y tampoco por tanto

7 Véase, extensamente, SánChez Melgar, J., Inviolabilidad e inmunidad de Diputados y Senadores, Ed. La Ley, Madrid 2013, pp. 173 y ss.

8 Véanse Del Moral García, A., Comentarios a los arts. 750 a 756 LECRIM, en Conde-Pumpido Ferreiro, C. (dir.), «Enjuiciamiento Criminal», Ed. Trivium, Madrid 1998, t. II, pp. 2663 y ss.; y MAGALdi Paternostro, M.J., Procedimientos especiales y actuación de oficio del juez: Análisis del procedimiento especial para el enjuiciamiento de diputados y senadores, en Adolfo de Prego de Oliver Tolívar (dir.), «Proceso penal y actuación de oficio de jueces y tribunales», Cuadernos de Derecho Judicial, Ed. CGPJ, Madrid 1995, pp. 355 y ss. 
de la ley penal. En consecuencia, el Derecho Constitucional, el Derecho Penal (y el Derecho Procesal Penal) no pueden ser interpretados conjuntamente de manera tal que se lleguen a establecer excepciones a la ley que signifiquen en realidad, vulnerando el principio constitucional de igualdad (art. $14 \mathrm{CE}$ ), que algunos ciudadanos están totalmente fuera del sistema penal siendo imposible exigirles ningún tipo de responsabilidad. Como está conclusión no es ni posible ni admisible en nuestro Derecho, la inviolabilidad sólo otorga penalmente una protección limitada.

Pues bien, la mejor doctrina penal entiende que la inviolabilidad penal comprende los delitos parlamentarios siguientes:

a) Delitos de opinión: La inviolabilidad penal tiene el límite material de alcanzar sólo a las opiniones y votos expresados y formulados por el diputado o senador (reflejo del sistema alemán). Se corresponde así con la inviolabilidad constitucional.

Dicho con otras palabras, no ampara cualquier actuación del parlamentario, sino únicamente las declaraciones de juicio o de voluntad. Esto implica que los delitos afectados sólo serán aquéllos cuya estructura típica descanse exclusivamente en la exteriorización de una opinión, es decir, en la manifestación de una voluntad, un pensamiento o un conocimiento. Podemos enumerar los siguientes delitos que estarían protegidos por la inviolabilidad penal:

1. Injurias a particulares o a autoridades (arts. 208 a 210 y 492 y ss. del Código Penal);

2. Calumnias contra particulares o contra autoridades (arts. 205 a 207 y 492 y ss. del Código Penal);

3. Amenazas (arts. 169 a 171 y concordantes del Código Penal);

4. Acusación y denuncia falsas (art. 456 del Código Penal);

5. Falsedades documentales (arts. 390 a 399 del Código Penal);

6. Usurpación de funciones públicas (art. 402 del Código Penal):

7. Descubrimiento y revelación de secretos que afecten a la intimidad (arts. 197 a 201 del Código Penal, reformados parcialmente en 2015);

8. Destrucción de documentos (art. 413 del Código Penal);

9. Infidelidad en la custodia de documentos (arts. 414 y ss. del Código Penal);

10. En relación con delitos de terrorismo, la apología o provocación para cometer delito de terrorismo (arts. 18.1, II y 571 a 580 del Código Penal, reformados parcialmente también en 2015), y el enaltecimiento del terrorismo (art. 578 del Código Penal), aunque con serias dudas en ambos casos al tratarse de provocar o de incitar a cometer delito; y

11. Incitación al odio, hostilidad, discriminación o violencia en los casos del largo art. $510 \mathrm{CP}$, introducido en 2015. Entre los nuevos delitos 
de odio, sigue penándose la apología del genocidio nazi, no así negar el nazismo, declarado inconstitucional según la antigua redacción del art. 607.2 por la S TC 235/2007, de 7 de noviembre, delito de negacionismo que ahora obviamente ha desaparecido.

De ellos destacan en la práctica como más comunes los delitos contra el honor, es decir, las injurias y calumnias.

Por la razón expuesta deben quedar fuera todos los demás delitos previstos por el Código Penal y leyes penales especiales, lo que significa que un amplísimo listado de delitos no estarían cubiertos por la inviolabilidad y serían perseguibles (salvo lo que decimos inmediatamente) desde el punto de vista procesal penal. En especial, deben quedar fuera expresamente aquellas conductas en donde, además de la opinión, sea necesaria la concurrencia de otra actuación, como la violencia exigida en el delito de coacciones. Como ejemplo real debemos poner la negativa a cumplir una sentencia judicial por el Presidente de un parlamento autonómico y por los miembros de la Mesa, que es delito conforme al art. 410 del Código Penal, delito no cubierto por la inviolabilidad parlamentaria9.

b) Otros delitos respecto a los que la cámara respectiva considere conveniente denegar el suplicatorio otorgando inmunidad: No debe dejar de decirse aquí, pues la jurisprudencia española demuestra que no basta con la afirmación de que quedan excluídos los delitos de opinión, que también quedan excluídos para el caso concreto aquellos delitos cuyo suplicatorio, solicitado en tiempo y forma por el órgano jurisdiccional competente, haya sido denegado por la cámara correspondiente.

Es verdad que en la época dictatorial franquista podían identificarse estos delitos con una cierta sistematización, por ejemplo, se denegó el suplicatorio siempre cuando el diputado imputado había cometido un delito de tráfico, pero el Parlamento no era democrático y la cita no debe entenderse más que puramente anecdótica. Hoy, con la democracia, no hay sistema posible. Si el Congreso de los Diputados decide no otorgar el suplicatorio contra un diputado acusado de maltrato de violencia de género, este delito queda protegido por la inmunidad, de forma claramente contraria a la Constitución porque nadie está autorizado a pegar a su mujer en ejercicio de sus funciones; lo mismo si el Senado decide denegar el suplicatorio por un delito de tráfico de influencias solicitado contra un senador. La dificultad que se plantea aquí es cómo puede obtener la víctima de esos delitos que se han introducido en la inmunidad penal, una tutela judicial efectiva, cuestión muy compleja y difícil, pues solamente tendría a su disposición el proceso (recurso) constitucional de amparo. Siempre estaría

9 Sentencia del Tribunal Supremo de 10 de noviembre de 2006, caso disolución por Parlamento Vasco de Sozialista Abertzaleak (Repertorio Aranzadi n. ${ }^{\circ}$ 6537). 
abierta la vía civil, es claro, pero la penal parece imposible. El recientísimo Estatuto de la Víctima del Delito (Ley 4/2015, de 27 de abril), no ha querido entrar en esta cuestión y por tanto es ineficaz para la víctima del delito en este punto.

c) Delitos cometidos por parlamentarios autonómicos: Una última precisión debe hacerse con relación a los parlamentarios autonómicos al no preverse especialmente en la Constitución su inviolabilidad, aunque sí en los Estatutos de Autonomía, ni tampoco su inmunidad. La razón de ello radica en que el constituyente pensó que no debía ser obligatorio que todas las comunidades autónomas tuvieran asamblea legislativa, bien porque no se deseaba extender hasta tal punto las prerrogativas parlamentarias, o bien, al contrario, porque se entendió que los parlamentarios autonómicos son parte integrante del poder legislativo del Estado. Así:

1. Todos los Estatutos de Autonomía prevén expresamente que sus parlamentarios gocen de inviolabilidad, en términos muy similares a los fijados por el art. 71.1 CE para los diputados y senadores del Estado. Por tanto, dado que el concepto es el mismo, vale lo indicado hasta aquí para los parlamentarios autonómicos también.

2. Pero no todos los Estatutos de Autonomía prevén la inmunidad con igual contenido y extensión, lo que para algún sector doctrinal significa que estamos ante una semi-inmunidad, y desde luego el trámite del suplicatorio no existe ante ninguna de ellas.

\section{LA DESIGUALDAD SOBRE LA DESIGUALDAD, DOS EJEMPLOS CLAMOROSOS}

Hasta aquí el manto dogmático que explica el aforamiento consecuencia de la inmunidad. Creemos que puede intuirse ya que la generosa regulación española ha de producir necesariamente muchas disfunciones, algunas de las cuales, las más importantes, llevan directamente a la desigualdad.

Pero antes y por si fueran poco alarmantes esas situaciones de desigualdad provocadas por privilegios procesales a las que genéricamente nos referimos ahora, puesto que las trataremos con detalle en el apartado IV, todavía el aforamiento ha sido utilizado para provocar más desigualdad, o si se prefiere, para establecer un privilegio reforzado sobre el privilegio del aforamiento, cuya inconstitucionalidad defenderé como he dicho en el apartado siguiente por violar el principio de igualdad.

Ahora me referiré a dos cuestiones que causan perplejidad: La exclusión del Tribunal del Jurado para los aforados a la Sala II del Tribunal Supremo, en clara vulneración de los arts. 1.3 y 2 de la Ley del Jurado de 1995; y la exclusión del aforamiento por conexión para quienes no están aforados a la Sala II del Tribunal 
Supremo, en contra del art. 17 LECRIM, tanto en su redacción vigente antes de la reforma de 2015 como después.

\section{La exclusión del Jurado para los aforados ante el Tribunal Supremo}

Este es un tema de gran dificultad jurídica, porque se mezcla de por medio la política ${ }^{10}$. La ley, que por cierto es orgánica, es muy clara: Cuando el delito cometido sea competencia del Tribunal del Jurado, pero ese delito lo haya sido por una persona aforada a la Sala II del Tribunal Supremo, el art. 2, en relación con el art. 1.3, ambos de la Ley del Jurado, no dan pie para prever ninguna excepción. Del texto legal parece deducirse inequívocamente que en todo caso la competencia es del Tribunal del Jurado ante el Tribunal Supremo.

Esto no plantearía mayores problemas si no fuera porque es nada menos la Constitución la que dice literalmente que el enjuiciamiento criminal de determinados aforados corresponde a la Sala II de lo Penal del Tribunal Supremo. Ello ocurre específicamente en el caso del Presidente y demás miembros del Gobierno, según el art. 102.1 CE, y en el de los diputados y senadores de las Cortes, de acuerdo con el art. 71.3 CE, como ya sabemos.

La cuestión es, entonces, si prevalece la dicción literal de estos preceptos que forman parte de la norma suprema del Ordenamiento Jurídico o, al contrario, si se entiende que el art. 2 Ley del Jurado desarrolla esos artículos CE, de manera que cuando el delito cometido por el diputado sea, por ejemplo, un homicidio doloso consumado, el tribunal competente deba ser en todo caso el Tribunal del Jurado del Tribunal Supremo.

Dos precisiones antes de continuar: La primera es que ninguno de los delitos previstos en el art. 102.2 CE es competencia del Tribunal del Jurado, por lo que estamos pensando, por seguir con el mismo ejemplo, en el caso de que el Presidente o un miembro del Gobierno cometan un delito de homicidio doloso o asesinato (el presidente del gobierno mata a su mujer). La segunda resulta de una posible bifurcación del problema, en caso de que el Presidente del Gobierno o el Ministro del Gobierno afectado sean parlamentarios (supuestos normales), pues aquí entraría en juego, para los delitos no previstos específicamente en el art. 102.2 CE, el art. 71.3 CE, sin necesidad de la ratificación del art. 102.1 CE; mientras que si el Presidente del Gobierno (lo que resulta inimaginable ciertamente), o algún Ministro (perfectamente posible), no son parlamentarios, entonces entraría en juego el art. 102.1 CE exclusivamente, que llega a la misma conclusión de aforamiento que la establecida para los parlamentarios. Por ello entendemos que el precepto clave a estos efectos es el art. 71.3 CE.

10 Véase más ampliamente Gómez Colomer, J.L., en Montero Aroca, J. / Gómez Colomer, J.L. (Coord.), Comentarios a la Ley del Jurado, Ed. Aranzadi, Pamplona 1999, pp. 282 a 287. 
Finalmente, en cuanto al planteamiento del tema, pero sin tener en cuenta esos delitos previstos por la Constitución específicamente para el Presidente del Gobierno y sus Ministros, no olvidemos que lo mismo podríamos decir respecto al Tribunal del Jurado del Tribunal Superior de Justicia, cuando el aforamiento es al Tribunal Superior de Justicia. Y así se ha cumplido en el único caso conocido hasta ahora, el caso Camps, ex-Presidente de la Generalidad Valenciana enjuiciado por un delito de cohecho impropio pasivo por el Tribunal del Jurado de la Sala de lo Civil y Penal del Tribunal Superior de Justicia de la Comunidad Valenciana ${ }^{11}$. Pero nadie dudará que el choque de mayor intensidad se produce en los casos constitucionalmente previstos.

Es claro que el fundamento constitucional, en lo que a nosotros afecta, no es otro que la voluntad del legislador constituyente de que los parlamentarios del Estado sean enjuiciados por el órgano judicial ordinario más elevado de la $\mathrm{Na}$ ción, dadas las especiales garantías que esta atribución conlleva con relación a las personas que ocupan las más altas responsabilidades políticas en España, lo que es particularmente relevante en el caso de que el parlamentario sea además Presidente o miembro del Gobierno.

De hecho, un sector doctrinal importante ${ }^{12}$ sostiene que el enjuiciamiento sólo puede ser a favor de la Sala II del Tribunal Supremo, y nunca del Tribunal del Jurado incardinado en el Tribunal Supremo, por el argumento formal-literal de que la Constitución española se refiere expresamente a la Sala II, y porque por el Pleno del Tribunal Supremo se dictó con fecha 27 de noviembre de 1998 un Acuerdo de Pleno no jurisdiccional ${ }^{13}$, en el que se acordó expresamente que:

«El enjuiciamiento de los diputados, senadores (art. 71.3 Constitución española) y miembros de la presidencia y demás miembros del Gobierno (art. 102.1 Constitución española), se tramitará ante la Sala II del Tribunal Supremo según las normas de procedimiento contenidas en la LECRim».

Este acuerdo otorgando la competencia a la Sala II del Tribunal Supremo, es para nosotros ilegal porque la decisión de qué órgano es competente es jurisdiccional y solamente se puede tomar mediante ley orgánica y no en una reunión de altos magistrados. El problema es que al haber sido incorporado ya a la jurisprudencia es prácticamente indestructible a no ser por el propio Tribunal Supremo en otra reunión igual, seguida a continuación de su incorporación a resoluciones del propio Alto Tribunal.

11 Causa n. ${ }^{\circ} 1 / 2011$ del Tribunal del Jurado, Sentencia n. ${ }^{\circ}$ 2/2012, de 30 de enero de 2012.

12 Véanse por ejemplo Gimeno Sendra, V. / Conde-Pumpido Tourón, C. / Garberí Llobregat, J., Los procesos penales, Ed. Bosch, Barcelona 2000, t. VI, p. 10; y GARCía MAHAMUT, R., La responsabilidad penal de los miembros del gobierno en la Constitución, Ed. Tecnos, Madrid 1999, pp. 124 y ss.

13 Recogido en Íñigo Corroza, E. / Ruiz de Erenchun Arteche, E., Los Acuerdos de Sala Penal del Tribunal Supremo: Naturaleza jurídica y contenido (1991-2007), Atelier, Madrid 2007, p. 231. 
Sorprendentemente, la Circular de la FGE 3/1995 de 27 de diciembre, sobre el Jurado, es de este parecer también (v. infra).

En nuestra opinión, la solución debe ser en favor del Tribunal del Jurado del Tribunal Supremo y no de la Sala II del mismo alto órgano jurisdiccional, por dos razones:

1. En primer lugar, por una razón jurídica, a saber, porque formalmente el Tribunal del Jurado es en este caso un órgano jurisdiccional incardinado en el ámbito del Tribunal Supremo, con lo que el tema de la literalidad de la expresión puede quedar soslayado. Preside además la fase de enjuiciamiento un Magistrado de la Sala II del Tribunal Supremo, y para el procedimiento preliminar y fase intermedia del proceso penal correspondiente sigue siendo instructor un Magistrado del Tribunal Supremo, conforme a las reglas generales (art. 57.2 LOPJ).

En otras palabras, el Tribunal del Jurado del Tribunal Supremo es Tribunal Supremo, o mejor, Sala II del Tribunal Supremo, lo que también vale para el Tribunal del Jurado del Tribunal Superior de Justicia, pues es Tribunal Superior de Justicia, o mejor, Sala de lo (Civil y) Penal del Tribunal Superior de Justicia, cuando por fuerza de su competencia objetiva, tengan que conocer del delito o delitos investigados contra las personas respectivamente aforadas.

No olvidemos tampoco, para reforzar esta idea, que si fueran tribunales distintos, con diversa jerarquía, se habría tenido que configurar al aprobar la Ley del Jurado un recurso de casación contra la decisión del Tribunal del Jurado del Tribunal Supremo, como está previsto cuando enjuicie el Tribunal del Jurado del Tribunal Superior de Justicia, y en ello no podía, correctamente, haber pensado la Ley, so pena de un error jurídico tan grave como vergonzoso científicamente.

2. Pero en segundo lugar, y mucho más importante en nuestra opinión, por otra razón de carácter político, porque al entrar la Ley del Jurado concretamente en la cuestión del aforamiento, y no sólo en esta norma que estamos comentando, habría salvado específicamente los casos previstos por la Constitución, en los que no podía dejar de pensar (la Audiencia Nacional no se le ha escapado, v. art. 1.3), y no lo ha hecho. La consecuencia a la que llegamos es que el art. $71.3 \mathrm{CE}$ se integra ahora con los arts. 1 y 2 Ley del Jurado, y no al revés.

Pero hay más consideraciones a tener en cuenta, dentro de esta motivación política, que se centran medularmente en el argumento democrático que rodea siempre a la institución del Jurado. En concreto, sería difícilmente explicable a la Sociedad que el Jurado es sólo para el pueblo, y no para los aforados. Aquí la desigualdad sobre la desigualdad a que nos referíamos. Un privilegio reforzado sobre el privilegio, En otras palabras, nadie creería en la voluntad del legislador 
a la hora de reconocer tan democrática institución, si éste se hubiera excluído a sí mismo de su aplicación. Tamaña bofetada antidemocrática sería irresistible y, además, sería discriminatoria hasta el absurdo, porque el diputado no estaría sujeto al Jurado y el Presidente del Tribunal Constitucional sí, cometiendo un delito de su competencia. Lo que es bueno para el pueblo llano, tiene que ser igualmente bueno para sus legítimos representantes, por tanto, todos deben caber y caben bajo el manto del Tribunal del Jurado, dados los demás requisitos legales. Si no, ¿para qué se ha creado el Tribunal del Jurado en el Tribunal Supremo? Pues para enjuiciar a aforados, entre los que están principalmente los diputados y senadores. No hay otra explicación posible.

Tengamos en cuenta incidentalmente que esta cuestión no afecta para nada al trámite de suplicatorio, que seguirá siendo un requisito de perseguibilidad absolutamente necesario. Tampoco afecta a si las personas aforadas cometen el delito como ciudadanos normales, porque la competencia objetiva, como en todos los demás casos orgánicos, se fija en abstracto, por lo que si el delito es de homicidio doloso, da igual quién lo haya cometido respecto a la competencia, pero no respecto al aforamiento, que sigue protegiendo al diputado o senador.

Por tanto, es clarísima para nosotros la interpretación que hay que dar a esos preceptos, pues no hay excepción alguna y siendo el Tribunal del Jurado competente, conoce en todo caso si el delito cometido por el aforado le está atribuido legalmente. Se puede plantear doctrinalmente, sin embargo, continuando con esta cuestión, una posible inconstitucionalidad del art. 2.1, II, en relación con el art. 1.3 Ley del Jurado, al menos formalmente por vulnerar el tenor literal de los arts. 71.3 y 102.1 CE, por estar aquéllos en clara contradicción con éstos, preceptos todos ellos que hay que poner en relación con el derecho fundamental al Juez ordinario predeterminado por la Ley del art. 24.2 CE, y también, si se atiende a la esencia del aforamiento, con el principio de igualdad procesal del art. 14 Constitución española.

Ciertamente, para los demás casos en los que por razones de aforamiento es también competente la Sala II del Tribunal Supremo, por ejemplo, todos los recogidos en el art. 57 Ley Orgánica del Poder Judicial, como el Presidente del Tribunal Supremo, el Presidente del Tribunal Constitucional, etc., no hay ningún problema de legalidad ordinaria. Una ley orgánica posterior ha efectuado un cambio competencial, manteniendo además el espíritu de la norma, y ello es perfectamente posible, atendido el art. 2.2 Código Civil. Pero seguiría subsistiendo la posible duda de inconstitucionalidad, no porque en definitiva no sea lo mismo el Tribunal del Jurado del Tribunal Superior de Justicia que la Sala Civil y Penal del Tribunal Superior de Justicia, con lo que podría pensarse que la Ley del Jurado ha cambiado el fuero autonómico, sino porque no habríamos resuelto el problema de si la Ley del Jurado ha respetado en esos preceptos el derecho al Juez legal indicado del art. 24.2 CE, o si puede haberse producido una vulneración de la igualdad tutelada en el art. 14 CE. 
Yendo, por tanto, al fondo de la cuestión, en nuestra opinión los órganos jurisdiccionales creados por la Ley del Jurado cumplen con el principio del juez legal. Se trata de una Ley, que además es como dijimos orgánica (art. 122.1 CE), que creó tribunales que han empezado a conocer de los asuntos atribuídos después de entrada en vigor la ley, por tanto, con competencia objetiva, funcional y territorial predeterminada, y que además están formados, tanto en su parte técnica como en la lega, por personal jurisdiccional fijo y provisional, cuya integración respeta el procedimiento legalmente establecido, fijado en la propia Ley del Jurado al regular un Tribunal especial salvado por la Constitución, ordenándose además el respeto al turno correspondiente, en relación con las normas pertinentes de la Ley Orgánica del Poder Judicial y complementarias al caso ${ }^{14}$. Los principios atinentes al personal jurisdiccional, básicamente la independencia e imparcialidad, también están regulados específicamente para el Tribunal del Jurado.

Ningún ciudadano, por tanto, podrá decir que con la Ley del Jurado en la mano, sin perjuicio de que en la práctica sí puedan producirse como es natural vulneraciones de este derecho, tiene garantizado el acceso al Tribunal Constitucional a través del recurso de amparo y su estimación, por el hecho de que él como aforado no puede ser enjuiciado por el Tribunal del Jurado del Tribunal Superior de Justicia, sino por el Tribunal Superior de Justicia, o que no puede ser enjuiciado por el Tribunal del Jurado del Tribunal Supremo, sino por el Tribunal Supremo. Tanto cumplen el principio del Juez legal el Tribunal Supremo, como el Tribunal del Jurado del Tribunal Supremo, a los efectos de las previsiones constitucionales. El problema no está por tanto en el principio del juez ordinario predeterminado por la ley.

En cuanto al principio de igualdad, resultaría absurdo, habiéndose creado el Tribunal del Jurado en los Tribunales Superiores de Justicia y el Tribunal del Jurado en el Tribunal Supremo para no vulnerar la igualdad respecto a los ciudadanos normales, manteniendo el aforamiento ante el mismo Tribunal, deducir una consecuencia precisamente violadora de ese principio de igualdad, cual es la de no admitir el Jurado en los casos en los que la Constitución establece expresamente la competencia de la Sala II del Tribunal Supremo, siendo el delito competencia del nuevo Tribunal. En relación con lo expuesto antes, ¿qué ejemplo estarían dando en este caso nuestros parlamentarios a las personas sobre las que legislan?

No parece argumento a tomar en consideración el de no haber previsto la Constitución española el Tribunal del Jurado en los arts. 102 y 73, porque aunque lo contempla en el art. 125, era imposible atendido el espíritu constitucional que la propia Constitución desarrollara las competencias del Jurado, ya que sólo quiso reconocerlo como órgano jurisdiccional, con lo cual estamos en todo caso ante una cuestión sobrevenida, no ante una falta de previsión constitucional.

14 Vide, entre otras, las Sentencias del Tribunal Constitucional 47/1983, de 31 de mayo; 101/1984, de 8 de noviembre; 197/1987, de 16 de diciembre; 95/1988, de 26 de mayo; y 68/2001, de 17 de marzo. 
Dados los anteriores argumentos no vemos formalmente que el art. 2.1, II, en relación con el art. 1.3, sea en este punto inconstitucional, ni por atentar contra el principio del juez legal, ni por poder suponer una vulneración del principio de igualdad, si se interpreta en el sentido favorable en todo caso al Tribunal del Jurado cuando el delito sea de los atribuídos a su competencia.

La Circular de la Fiscalía General del Estado 3/1995, de 27 de diciembre, dando criterios de actuación del Ministerio Fiscal en el proceso ante el Tribunal del Jurado, es de la misma opinión cuando el aforamiento venga referido al Tribunal Superior de Justicia, concluyendo que el Tribunal del Jurado del Tribunal Superior de Justicia no vulnera el principio del Juez legal al tratarse de dos leyes orgánicas y que, por tanto, éste será competente en todo caso si el delito es de los atribuídos a su competencia. Pero sorprendentemente, cuando el aforamiento sea a la Sala II del Tribunal Supremo, entiende que en ningún caso es de aplicación la Ley del Jurado, porque los arts. 102.1 y 71.3 Constitución española «no pueden verse modificados por los arts. 1 y 2 de la Ley Orgánica del Tribunal del Jurado». Para la Fiscalía General del Estado la Sala II es diferente a un Tribunal compuesto por nueve jurados y un Magistrado del Tribunal Supremo que lo presidirá, opinión que compartimos, desde luego, pero no sabemos bien a qué viene a cuento. Esta opinión tiene el apoyo de cierto sector doctrinal práctico ${ }^{15}$. Para nosotros la clave está en cómo se integran, si se integran estos tribunales, y en si se respeta la institución del aforamiento y las garantías con esta solución.

Pero el Tribunal Supremo, en la primera oportunidad que tuvo sobre el tema, decidió en el sentido propugnado por la Fiscalía General del Estado, al entender el Excmo. Sr. Magistrado-Instructor de la causa contra un senador, por un presunto delito de malversación de caudales públicos, que debía rechazar la sustanciación por el procedimiento ante el Tribunal del Jurado, decisión solicitada tanto por el Ministerio Fiscal como por el propio querellado aforado, incluso por la acusación particular. La razón, según el Auto de 9 de febrero de $1999^{16}$, porque la Sala Segunda del Tribunal Supremo tiene el máximo rango legal para asegurar el enjuiciamiento de aforados, ya que «el órgano jurisdiccional permanente y predeterminado [para juzgar a Diputados y Senadores] es la Sala Segunda del Tribunal Supremo, la cual en modo alguno puede identificarse con un órgano jurisdiccional "ad hoc" compuesto por los nueve jurados que han de emitir el veredicto, aunque sean presididos por un magistrado de dicha Sala» ${ }^{17}$.

15 Por ejemplo, Conde-Pumpido Tourón, en Arnaldo Alcubilla et als., Manual del Jurado, Abella, Madrid 1996, p. 50.

16 Causa especial n. ${ }^{\circ} 4030 / 1997$.

17 Razonamiento Jurídico Único, párrafos III y IV; auto que por cierto mereció ser noticia destacada en periódicos de tirada nacional (por ejemplo, el Diario EL PAIS, edición nacional, sábado 13 de febrero de 1999, p. 20). 
A la vista de la anterior argumentación, pensamos que es una decisión muy desafortunada, claramente contra el principio pro Jurado, y, además, que favorece la propia «huída» del Jurado, tan certeramente denunciada por el Consejo General del Poder Judicial. Insistimos, el Tribunal del Jurado del Tribunal Supremo, es Tribunal Supremo porque se incardina en su Sala II, aunque sea un tribunal especial, y además la bofetada antidemocrática al pueblo es clamorosa, pues más o menos lo que se está diciendo es: «Quede para el pueblo llano el Jurado, que el mejor tribunal técnico se lo reserva el aforado», el Supremo nada menos.

Para finalizar esta cuestión y desde otra perspectiva, debemos preguntarnos ahora si realmente el legislador ha sido consciente del grandísimo cambio que estas normas implican. Es fácil colegir que no se ha querido motivar intencionadamente una infracción del principio de igualdad, incluso que dentro del espíritu de libertades que el Jurado representa, se haya considerado más democrático que el Jurado intervenga sea cual fuere la calidad de la persona ${ }^{18}$.

No obstante, dejando de lado que el aforamiento en la mayor parte de los muchísimos casos que prevé la legislación española ya implica, al menos, un cierto roce con el principio de igualdad, cuando no una clara vulneración, el art. 2.1, II va directamente en contra de la esencia del aforamiento, de la razón nuclear del privilegio, puesto que éste existe para garantizar al favorecido por él que sólo un tribunal superior, el máximo ordinario de España si estamos ante el Tribunal Supremo, es por su valía y competencia profesional capaz de resolver los posibles hechos delictivos de personas que, por su cargo, pueden verse tan injusta como constantemente atacadas por sus enemigos políticos y personales, amenazantes con el temor que toda imputación debe conllevar. ¿Qué calidad jurídica se sostiene, al menos igual y equiparativamente, cuando entran en liza, con todos los respetos, ciudadanos legos?, ¿qué especiales garantías se mantienen en estos casos para los aforados?, ¿qué decir de la pérdida de recursos para estas personas?, etc. Esto da pie para hablar sin reparos de «huída del aforado del Jurado» ${ }^{19}$. Estas dudas parecen haber justificado el Acuerdo del Pleno no Jurisdiccional de la Sala II del Tribunal Supremo de 1998 al que hemos hecho referencia supra.

Pero aunque formalmente pensamos que no hay ninguna infracción constitucional, como acabamos de razonar, y aunque nos reafirmemos en la competencia del Tribunal del Jurado del Tribunal Supremo para enjuiciar a diputados y senadores dándose los demás requisitos legales, lo cierto es que el espíritu de la

18 Desde luego, no tiene precedentes en algunos de los países más próximos a nuestro entorno cultural. Véase el excelente artículo de Tiedemann, K., Indemnidad, inmunidad y acusación de Funcionarios en el Derecho Constitucional y en el Derecho Procesal Penal alemán y extranjero, Revista de Derecho Procesal 1999, n. ${ }^{\circ}$ 1, pp. 111 y ss. (publicado también en Juan-Luis Gómez Colomer, «Constitución y Derecho Penal», Palestra, Lima 2003, pp. 127 y ss.).

19 Nuestra Ley del Jurado de 1888, no únicamente sabia por vieja, excepcionó precisamente por estos temas de la competencia del Tribunal del Jurado los delitos cuyo conocimiento correspondía al Tribunal Supremo (art. 5). 
Constitución de alguna manera se altera, pues se sustituye toda una Sala del Tribunal Supremo, formada exclusivamente por Magistrados técnicos, por un Magistrado técnico del mismo Tribunal y nueve ciudadanos legos, que ni tienen, ni pueden tener, ni la misma categoría ni equivalente. Pero de ello es responsable el legislador, no su intérprete.

Los mismos argumentos sirven para el Tribunal del Jurado que se incardina en el Tribunal Superior de Justicia. En definitiva, si no es para enjuiciar a aforados, ¿para qué se ha previsto el Tribunal del Jurado en el Tribunal Superior de Justicia?

Por ello tenemos que concluir, insistiendo en algo ya dicho, que no nos parece un acierto que se haya previsto el Tribunal del Jurado en los Tribunales Superiores de Justicia y en el Tribunal Supremo, porque a la vista de lo argumentado, ello plantea más problemas que resuelve.

\section{La exclusión del aforamiento por conexión para quienes no están aforados a la Sala II del Tribunal Supremo}

Un segundo problema aumenta todavía más si cabe la desigualdad de los desiguales, es decir, privilegia más al privilegiado. Es el tema de la separación de causas cuando son investigados (imputados) un aforado ante el Tribunal Supremo y otro aforado ante el Tribunal Superior de Justicia, y quizás otra persona «normal», es decir, no aforada en absoluto.

La máxima ha sido en principio hasta hace bien poco que el tribunal superior atraía la competencia sobre el inferior por aplicación de las reglas de conexión, de manera que en el ejemplo puesto el Tribunal Supremo conocía del proceso penal contra todos los imputados (investigados, encausados). Las razones principales: Evitar sentencias contradictorias y aplicar criterios de economía procesal. Pero sorprendentemente el Tribunal Supremo se ha encargado de romper con esa regla para quitarse de encima causas complejas, demasiado complicadas o enrevesadas, cuando un aforado ante el mismo estaba siendo investigado junto con otras personas no aforadas o aforadas a distinto tribunal.

La LECRIM sentó desde 1882 en su art. 300 la regla de que cada delito de que conozca la autoridad judicial será objeto de un sumario, excepcionando a continuación los delitos conexos, que deben enjuiciarse en un solo proceso. En este precepto basaba la jurisprudencia la anterior máxima. Hoy ese precepto está derogado (por la Ley 41/2015, de 5 de octubre), pero esa regla se contiene en el nuevo art. 17.1 LECRIM, que ha sido reformado por la misma Ley 41/2015, para ajustar las normas de conexión a la realidad actual de una manera más efectiva.

En efecto, la LECRIM sienta en su art. 17.1 la misma regla: Cada delito de que conozca la autoridad judicial será objeto de un sumario y a continuación excepciona los delitos conexos, pues éstos deben comprenderse en un solo proceso. Y añade ahora: «cuando la investigación y la prueba en conjunto de los hechos 
resulte conveniente para su esclarecimiento y la determinación de las responsabilidades procedentes». Pero si a pesar de ello existe una «excesiva complejidad o dilación para el proceso», se enjuician por separado.

Esta es la norma española para evitar los últimos procesos «monstruo» que hemos tenido y seguimos teniendo en España ${ }^{20}$.

La conexión entendida en sentido estricto (diversidad de delitos culpándose a una sola persona o a varias), puede ser determinante tanto de jurisdicción (competencia genérica), como de competencia objetiva y territorial. La ley no se ocupa de los delitos conexos sino a tales efectos, olvidando, después de establecer el efecto más importante de la acumulación, a saber, el enjuiciamiento en un único proceso (art. 17.1), la forma de hacerlo efectivo o de impugnarlo, además de establecer una regla específica para un incidente de la ejecución en el art. 988 LECRIM. La acumulación tiene repercusión en la competencia cuando cada uno de los delitos, de perseguirse por separado, correspondería a un órgano distinto.

Es la propia LECRIM la que nos dice cuándo existe conexión en su art. 17 (reformado por la Ley 41/2015, de 5 de octubre):

1. Comisión simultánea (art. 17.2-1 ${ }^{\circ}$ ): Son delitos conexos los cometidos por dos o más personas reunidas. Se supone, ante el silencio de la ley que la comisión debe ser simultánea y que esas personas deben venir sujetas a diversos órganos jurisdiccionales ordinarios o especiales, o que puedan estarlo por la naturaleza del delito. Pero, obsérvese, si esas personas presuntas autoras no están sometidas a diversos jueces y tribunales, también se produce la conexión, aunque no se altera la competencia;

2. Comisión bajo acuerdo (art. 17.2-2 ${ }^{\circ}$ ): Son también conexos los delitos cometidos por dos o más personas en distintos lugares o tiempos, si hubiera precedido acuerdo para ello;

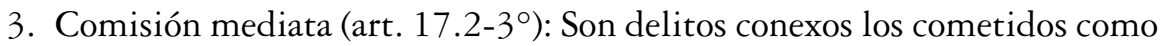
medio para perpetrar otros o facilitar su ejecución;

4. Comisión para impunidad (art. 17.2-4º): También se consideran legalmente delitos conexos los cometidos para procurar la impunidad de otros delitos;

5. Por decisión de la ley (art. 17.2-5.. ): Los delitos de favorecimiento real y personal y el blanqueo de capitales respecto al delito antecedente. Es una causa de conexidad nueva en nuestro Derecho Procesal, impuesta por la realidad práctica;

6. Comisión de daños recíprocos (art. 17.2-6.. ): Los cometidos por diversas personas cuando se ocasionen lesiones o daños recíprocos. Causa también nueva; $\mathrm{y}$

20 Por ejemplo, caso de los ERE, v. Auto de la Audiencia Provincial de Sevilla Sec. 7.a n. 938/2013, de 13 de diciembre de 2013, y Auto del Tribunal Supremo de 13 de noviembre de 2014 (JUR $\backslash 272065$, caso Gürtel); v. también el Auto del Tribunal Supremo de 19 de junio de 2012 (JUR 252202, etc.). 
7. Comisión análoga (art. 17.3): Los delitos que no sean conexos pero que hayan sido cometidos por la misma persona y tengan analogía o relación entre sí, cuando sean de la competencia del mismo órgano judicial, podrán ser enjuiciados en la misma causa, a instancia del Ministerio Fiscal, si la investigación y la prueba en conjunto de los hechos resulta conveniente para su esclarecimiento y la determinación de las responsabilidades procedentes, salvo que suponga excesiva complejidad o dilación para el proceso.

Es un matiz de la causa ya existente antes de la reforma, que por cierto no se quiso asumir para el Tribunal del Jurado (art. 5.2 Ley del Jurado), aunque ello no siempre haya sido posible. En esta causa se incardinan la mayor parte de los supuestos de conexión entre aforados y no aforados.

En caso de delitos conexos con delitos de violencia de género, conoce también el Juzgado de Violencia sobre la Mujer, siempre que la conexión tenga su origen en alguno de los supuestos previstos en los números $3 .^{\circ}$ y $4 .^{\circ}$ del artículo 17 (art. 17 bis LECRIM). Es decir, la conexión sólo será admisible si se funda en la comisión mediata, o en la comisión para impunidad.

La LECRIM también determina en su art. 18.1 los fueros competenciales existiendo conexión de delitos. En este sentido, son jueces y tribunales competentes, por su orden, para conocer de las causas por delitos conexos:

a) Fuero principal de la gravedad de la pena (art. 18-1 ${ }^{\circ}$ ): Conoce el órgano jurisdiccional del territorio en que se haya cometido el delito al que esté señalada pena mayor;

b) Fuero subsidiario temporal (art. $18-2^{\circ}$ ): Si los delitos tienen señalada igual pena en las leyes, conoce el órgano jurisdiccional que primero hubiera comenzado las actuaciones; y

c) Fuero supletorio de la orden (art. 18- $3^{\circ}$ ): Si las causas hubieran comenzado al mismo tiempo, o no constara qué órgano empezó antes, conoce el órgano jurisdiccional que la AP o el Tribunal Supremo, en sus casos respectivos, designen.

Cuando se trate de comisión bajo acuerdo, el art. 18.2 establece un fuero específico con preferencia sobre los anteriores: El fuero de la sede de la Audiencia Provincial, siempre que los distintos delitos se hubieren cometido en el territorio de una misma provincia y al menos uno de ellos se hubiera perpetrado dentro del partido judicial sede de la correspondiente Audiencia Provincial. Asume la competencia, por tanto, el órgano jurisdiccional correspondiente de la capital de provincia.

Pero como agudamente ha observado cierto sector doctrinal práctico muy importante, la determinación de la competencia objetiva por conexión no debe 
operar automáticamente, puesto que siempre que sea posible separar los delitos sin poner en peligro la continencia de la causa, no habrá conexión, y por tanto cada tribunal enjuiciará a su aforado ${ }^{21}$.

Pues bien, resulta obvio que uno de los presuntos autores de delitos conexos puede ser perfectamente una persona aforada. Dos preguntas surgen inmediatamente, ninguna de las cuales está resuelta expresamente por la ley: ¿Qué ocurre cuando los delitos son cometidos por personas que están aforadas a distintos tribunales, y qué ocurre en segundo lugar cuando los delitos son cometidos por una persona aforada y por otra que no lo es?

\section{A) El enjuiciamiento de aforados a distintos tribunales}

La primera de las cuestiones se plantea cuando diversos crímenes que deben juzgarse por conexión en una sola causa, por ejemplo, porque varias estafas cometidas bajo acuerdo, lo han sido por un senador, aforado a la Sala II del Tribunal Supremo, y por un parlamentario autonómico, aforado al Tribunal Superior de Justicia de su comunidad autónoma porque él cometió el delito en dicho territorio.

Las únicas normas en las que se puede apoyar una solución razonable son el art. 272, II LECRIM, en virtud del cual, si la persona contra la que se dirija la querella es un aforado «a determinado tribunal, ante ése se interpondrá la querella» (en relación con el art. 4 de la Ley de 9 de febrero de 1912); y el art. 21 LECRIM, que prohíbe la sustanciación de cuestiones de competencia al Tribunal Supremo. También nos puede servir de apoyo una máxima competencial que nuestras leyes de enjuiciamiento siempre han tenido en cuenta: «Quien puede lo más, puede lo menos».

Por otra parte, la situación puede ser más compleja de lo que parece, porque muchos Estatutos de Autonomía determinan dos fueros distintos para sus parlamentarios, según comentan el delito en el territorio de su Comunidad Autónoma (el Tribunal Superior de Justicia), o fuera de él (el Tribunal Supremo) ${ }^{22}$.

Pues bien, la interpretación jurisprudencial se acomodaba hasta hace bien poco a la regla de que es el tribunal jerárquicamente superior de los dos el que atrae la competencia para sí, de manera que por conexión resultará competente en el ejemplo puesto el Tribunal Supremo. Lo mismo respecto a los Tribunales Superiores de Justicia con relación a la Audiencia Provincial ${ }^{23}$. Esta solución podía

21 Véase Marchena Gómez, M., Procesos penales contra aforados, en SaAvedra Ruiz, J. (dir.), «Cuestiones de Derecho Procesal Penal», Cuadernos de Derecho Judicial, CGPJ, Madrid 1994, pp. 506 y 507.

22 Por ejemplo, el art. 23.3, II Estatuto de Autonomía de la Comunidad Valenciana de 1982, últimamente reformado en 2010.

23 Véase Flors Matíes, J., La Sala de lo Civil y Penal del Tribunal Superior de Justicia. Constitución, composición, competencia y especialidades procesales, cit., p. 201. 
apoyarse también, de manera endeble ciertamente porque está superada en este

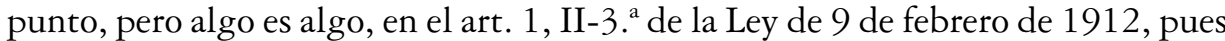
si eran enjuiciados un diputado y un militar aforado, conocía el Tribunal Supremo y no el Consejo Supremo de Guerra y Marina.

\section{B) El enjuiciamiento de aforados y no aforados}

Más común puede ser el hecho de que el senador, aforado a la Sala II del Tribunal Supremo como sabemos, cometa varios delitos, por ejemplo, apropiaciones indebidas bajo acuerdo con otra persona que no está aforada a ningún tribunal, un contable de una multinacional por ejemplo.

La solución acabada de ofrecer en el supuesto primero era hasta ahora igualmente plenamente aplicable aquí, razón por la que el Tribunal Supremo, en el ejemplo dado, sería el competente, salvo que fuera posible el enjuiciamiento separado, en cuyo caso al senador lo enjuiciaría el Tribunal Supremo, y al otro acusado, el que correspondiese conforme a las reglas ordinarias de competencia objetiva, funcional y territorial.

\section{C) El rompimiento del criterio por el Tribunal Supremo}

La regla enunciada sólo tenía una excepción, no prevista expresamente por la ley pero formulada jurisprudencial y doctrinalmente con base en el derogado art. 300 (hoy art. 17.1 LECRIM), a saber, que el enjuiciamiento pudiera hacerse por separado sin romper la continencia de la causa. Por tanto, la determinación de la competencia objetiva por conexión no se fijaba automáticamente, puesto que siempre que fuese posible separar los delitos sin poner en peligro la continencia de la causa, no habría conexión, y por tanto cada tribunal enjuiciaría a su aforado.

La reforma de 2015 ha añadido otras dos causas para alterar la regla: Que el enjuiciamiento de los delitos conexos en un único proceso sea excesivamente complejo, o que dilate la causa excesivamente, en cuyo caso se enjuiciarán por separado (art. 17.1, II LECRIM).

Esto ha llevado en realidad a que la regla tradicional de conexidad en caso de aforamiento de uno de los autores del delito ya no exista, o al menos, a que sea muy fácilmente ladeada.

El estado de la cuestión a día de hoy es el siguiente: Tradicionalmente como hemos visto se ha entendido que cuando un delito era cometido por una persona aforada y por otra no aforada una regla de conexión (ex anterior art. 17-5. ${ }^{\circ} \mathrm{LE}-$ CRIM) obligaba a que el Tribunal Supremo enjuiciara al no aforado conjuntamente con el aforado. Con el nacimiento de las Autonomías, se entendió que la regla era la misma para el caso de que cometiera un delito un aforado ante el Tribunal Supremo y otro aforado, pero ante el Tribunal Superior de Justicia. 
No existía ni existe después de las grandes reformas de la LECRIM de 2015 una norma expresa que obligue al enjuiciamiento conjunto, y el único fundamento legal era realmente indirecto, la norma de conexidad citada.

Pero el Tribunal Supremo ha cambiado jurisprudencialmente este criterio, a la vista de ciertas causas complejas que desde el año 2006 (aunque en realidad las decisiones más importantes se toman a partir de 2013) le van llegando con presencia de numerosos imputados, aforados ante el Tribunal Supremo, aforados ante el Tribunal Superior de Justicia, y no aforados, a veces más de 200, y ante lo ingente de la documentación, a veces más de 100.000 folios. Es decir, ha tomado una decisión de romper la conexidad para evitar el tener que investigar y juzgar un macroproceso.

Para ello ha intentado dotar a la decisión de un empaque dogmático que en realidad esconde un debate falso:

1. Ha entendido de manera diferente a como se hacía hasta ahora que estábamos ante un problema de juez legal. Con base en dos sentencias del Tribunal Europeo de Derechos Humanos ${ }^{24}$, el Tribunal Supremo ha pasado a sostener un criterio muy estricto. En esas sentencias se decide en casos de enjuiciamientos conjuntos de un ministro belga con el de otras personas no aforadas, juzgadas todas ellas por el tribunal en principio competente para el aforamiento, dar la razón a los no aforados reconociendo que se había vulnerado su derecho al juez ordinario, porque el TEDH entiende que si no existe en la ley una regla expresa de conexidad para el enjuiciamiento de aforados y no aforados, éstos deben ser enjuiciados por los tribunales ordinarios que respeten el principio del juez legal, so pena de violar el art. 6.1 del Convenio Europeo de Derechos Humanos.

2. Ha negado las ventajas de la acumulación de procesos en los casos de macroprocesos.

3. Ha remarcado los perjuicios que conlleva la acumulación, básicamente que la complejidad redunda en dilaciones en la tramitación y la disparatada prolongación de las sesiones del juicio oral.

4. Ha distendido la excepción de la continencia de la causa, principio con el que, al acumular varios procesos en uno sólo, se pretenden evitar sentencias contradictorias y procurar una adecuada investigación de todos los hechos, en el sentido de que entiende que debe romperse con la continencia de la causa y dividirla cuando su respeto pueda llevar a macroprocesos que generarían graves dilaciones indebidas en su tramitación.

24 Se trata de la S TEDH de 2 de junio de 2005, LA LEY 125234/2005/, Caso Claes contra Bélgica, ap. 39 a 41; y de la S TEDH de 22 de junio de 2000, ECLI:Constitución española:ECHR:2000:0622JUD003249296, Caso Coëme y otros contra Bélgica, ap. 94 a 110). 
5. Ha fijado que el art. 17-5. ${ }^{\circ}$ y concordantes como los arts. 272, 300, 303 y 304 LECRIM) no es norma suficiente de conexidad y por tanto, no puede vulnerarse el principio del juez legal, ya que lo único cierto es que el Tribunal Supremo (o en su caso el Tribunal Superior de Justicia) es el juez legal para los aforados ${ }^{25}$, y no lo es para los no aforados.

Y en consecuencia ha establecido la siguiente doctrina jurisprudencial:

a) La investigación de los aforados puede hacerse separadamente de los no aforados cuando su actuación, su entidad y su autonomía estén claramente diferenciadas entre sí.

b) Sólo cuando exista una conexión material inescindible entre todos los imputados el no romper la continencia de la causa obligará a su enjuiciamiento conjunto en el Tribunal Supremo (o Tribunal Superior de Justicia).

c) Para prevenir el cumplimiento de esta doctrina, los órganos competentes para los no aforados deberán remitir al Tribunal Supremo cuantos datos resulten de las diligencias que se practiquen que tengan relación con los hechos atribuidos provisionalmente a las personas aforadas ante el Tribunal Supremo.

Por tanto, la doctrina clásica ha muerto, y no por un acuerdo de Pleno no Jurisdiccional, como pareciera según la costumbre del Tribunal Supremo, sino mediante doctrina contenida en Autos del más alto tribunal español ordinario, con el único fin de evitar que la Sala II tenga que instruir (investigar) y juzgar (enjuiciar) a personas no aforadas que sean co-imputadas al mismo tiempo con personas aforadas.

Para comprobar la veracidad de nuestra afirmación, véase lo que dice el Auto del Tribunal Supremo, Sala II, de 13 de noviembre de 2014²6:

\section{RAZONAMIENTOS JURÍDICOS}

«TERCERO. En cuanto a la posibilidad de atraer a la competencia de esta Sala respecto de hechos ejecutados por personas no aforadas ante la misma, de un lado, y sin olvidar la importancia que puede presentar la visión de conjunto, procede señalar la conveniencia de que se respete en la máxima medida posible el derecho al juez ordinario respecto de cada una de las personas a las que se imputan hechos punibles (Autos de 29 de junio de 2006 y 23 de junio de 2009).

De otro lado, y además de lo que tales consideraciones implican, es pertinente recordar lo que ya esta Sala advertía en la Sentencia del Tribunal Supremo n. ${ }^{\circ}$ 990/2013, de 30 de diciembre, citada por el Ministerio Fiscal: Aun no siendo

26 Rec. 20619/2014, LA LEY 152532/2014, caso ERES de Andalucía. 
esta sentencia el lugar para una exposición del problema que suelen suscitar los denominados macroprocesos, sí debemos al menos una mínima reflexión sobre esa práctica de dudosa pertinencia.

La nada escasa indeterminación del criterio de conexidad establecido en el n. ${ }^{\circ} 5$ del artículo 17 de la Ley de Enjuiciamiento Criminal no debe impedir la ponderación de intereses contrapuestos en el trance de decidir la acumulación de procesos, con sendos y diferenciados objetos, en un único procedimiento. Más si cabe, cuando las pretendidas ventajas de dicha acumulación son de relevancia muy inferior a la de los perjuicios que conlleva.

Por un lado, por la complejidad que redunda en dilaciones de la tramitación. Dilaciones que no se acarrearían en el caso de plurales procedimientos e intervención de pluralidad de órganos jurisdiccionales. Ejemplo de ello es la tantas veces aludida tramitación de la causa desgajada del procedimiento origen de este recurso, al que se vienen refiriendo como caso Metro 3.

La disparatada prolongación de las sesiones de juicio oral, con separaciones en el tiempo de pruebas que versan sobre hechos diversos, en la medida de la flaqueza de la humana memoria, se puede traducir, en un debilitamiento de los deseables beneficios de la inmediación.

No son desdeñables los perjuicios que implica trasladar a algunos de los sujetos pasivos del procedimiento las consecuencias gravosas inherentes a la dilación, que encuentra su causa en las exigencias temporales de las actuaciones seguidas respecto de otros sujetos, en nada relacionados con los demás intervinientes.

Por otra parte, los supuestos beneficios de la acumulación no parecen siempre de obligada renuncia, en caso de tramitación autónoma del procedimiento. Incluso cuando algunos de los sujetos tengan participación en todos los hechos objeto de cada uno de los procesos acumulados. Ni en cuanto a la prueba, pues siempre será menos onerosa la parcial reiteración de la misma en diversos procedimientos de los concretos aspectos comunes, que subordinar la duración de lo sencillamente enjuiciable a la demora exigida por lo de enjuiciamiento dificultoso. Ni en cuanto a los beneficios penológicos para el reo, a cuyos efectos la Ley de Enjuiciamiento Criminal prevé los mecanismos necesarios (artículo 988).

De ahí que, como ocurre en el presente caso, la complejidad haya sido generada en buena medida por una harto cuestionable decisión de acumulación. A la cual desde luego son ajenos los diversos acusados.

En consecuencia, la extensión de la competencia a hechos cometidos por personas no aforadas ante el Tribunal Supremo solamente será procedente cuando se aprecie una conexión material inescindible con los imputados a las personas aforadas, lo cual puede apreciarse, en algunos casos, desde un primer momento, y, en otros, ser resultado de la investigación, lo que determinará, en este último supuesto, que la Sala adopte las pertinentes resoluciones sobre el particular, a propuesta del instructor.

CUARTO. En el caso, tal como sostiene el Ministerio Fiscal, en principio es posible investigar y enjuiciar de forma independiente los hechos relativos a la ideación, diseño, organización y establecimiento del sistema, así como las actuaciones consistentes en decisiones que en el tiempo supusieron su mantenimiento operativo, en las que, indiciariamente y según la Exposición razonada, han intervenido los aforados ante esta Sala, junto con los hechos concretos imputados a cualquiera de 
ellos, sin necesidad de proceder, al mismo tiempo, a la investigación y, después y en su caso, al enjuiciamiento conjunto, de todas las conductas concretas de ejecución administrativa y material de las acciones permitidas por dicho sistema, imputadas a otras personas. Como se ha dicho antes, sin perjuicio de las precisiones particulares que la investigación pueda ir requiriendo en función de sus resultados, que pueden hacer aconsejable la ampliación del conocimiento de esta Sala a hechos cometidos por personas no aforadas pero que presenten, como se ha dicho más arriba, una conexión material inescindible con los imputados a las personas aforadas.

El resto del procedimiento deberá continuar ante los órganos competentes, sin perjuicio de que remitan a esta Sala cuantos datos resulten de las diligencias que practiquen que tengan relación con los hechos atribuidos provisionalmente a las personas aforadas ante esta Sala.

QUINTO. Si como consecuencia de las diligencias de investigación el Instructor aprecia la existencia de indicios racionales de criminalidad contra cualquiera de los aforados deberá exponerlo a esta Sala a los efectos de la solicitud de Suplicatorio, conforme al art. 71.2 CE, con carácter previo a su inculpación formal, procesamiento, o adopción de cualquier medida cautelar (Auto de 31 de enero de 2013).»

Por ello el Tribunal Supremo acuerda en su PARTE DISPOSITIVA: $\cdots$

«3. . Respecto a los hechos imputados a otras personas no aforadas ante esta Sala, el procedimiento deberá continuar ante el órgano competente, sin perjuicio de que remita a esta Sala todo aquello que tenga relación con las mencionadas personas, aforadas ante la misma.»

Esta doctrina acaba de ser ratificada en el Caso Homs (Auto del Tribunal Supremo de 25 de mayo de $2016^{27}$ ). No es sin embargo doctrina unánime. Disiente, con sólidos argumentos y defiende la continencia de la causa y su inescindibilidad, el Auto del Tribunal Supremo de 24 de junio de $2015^{28}$.

\section{EL ANÁLISIS JURÍDICO DEL AFORAMIENTO: UNA CLARA VULNERACIÓN DEL PRINCIPIO CONSTITUCIONAL DE IGUALDAD}

Creemos que varios de los muchos privilegios de los altos cargos, autoridades y funcionarios públicos descritos en estas páginas, tal y como están regulados en España en la actualidad pueden vulnerar el principio de igualdad procesal del art. $14 \mathrm{CE}$ en su mayor parte, y por tanto deberían ser suprimidos del ordenamiento jurídico cuanto antes ${ }^{29}$. Me fijaré sólo en los aforamientos procesales para

27 Causa especial recurso 20249/2016, RA JUR 2016 126276 , Razonamiento Jurídico 4.

28 Causa especial n. ${ }^{\circ}$ 20619/2014 (caso GRIÑÁN, JUR 2015 \165305).

29 Lo he explicado con detalle en Gómez Colomer, J.L., Sobre aforamientos y principio de igualdad, Revista de Derecho Procesal (volumen homenaje al Prof. Pedro Aragoneses) 2009, pp. 499 a 537. 
demostrar esta tajante conclusión, dejando por ahora de lado argumentaciones sustantivas que afectan a la posible inconstitucionalidad de determinados casos de inviolabilidad, y de muchos supuestos de inmunidad.

Recordemos que el aforamiento en España implica que de la causa penal conoce la Audiencia Provincial ${ }^{30}$, el Tribunal Superior de Justicia o el Tribunal Supremo, de acuerdo con la competencia objetiva y funcional que establecen o la Constitución o una ley orgánica específicamente, que afecta en estos momentos en España como ya hemos dicho a más de 250.000 altas autoridades, funcionarios y cargos públicos.

Pues bien, en nuestra opinión los aforamientos vulnerarían el art. 14 CE por cuatro razones principalmente:

a) La primera es de naturaleza dogmática, y tiene que ver con un exagerado desarrollo autoproteccionista de la inmunidad, sobre todo de la inmunidad parlamentaria. Incluso en aquellos países que tienen sólo uno o dos aforamientos, la doctrina científica y la jurisprudencial se quejan de las extralimitaciones que suceden en la práctica del privilegio de la inmunidad, de hecho, argumentan con casos prácticos reales que la inmunidad se está aduciendo en verdad para procurar impunidad al favorecido por ella. ¿Qué pensarán cuando lean lo que sucede en España? ¿No es suficiente con que los favorecidos por la inmunidad estén protegidos frente a detenciones con fundamento político? La protección legalmente dispensada en España es, muy al contrario, frente al mismo proceso penal y a cualquier institución procesal que pueda perturbarles más allá de lo que su gran responsabilidad política o funcionarial tolera: Querella, detención, actos de investigación previos, competencia del más alto tribunal, reuniones parlamentarias o de grupo secretas para decidir autorizaciones, declaración judicial, prisión provisional, inculpación o procesamiento, en fin, sobreseimiento libre. Incluso se sostiene en España, respecto a los jueces, que el aforamiento persiste aunque se jubilen o cesen estando encausa$\operatorname{dos}^{31}$, algo que nos parece inadmisible. Sin duda ello es debido al extendido mal del corporativismo, pero también a que por la inmunidad los beneficiados por ella se convierten en juez y parte de sus propios actos, sin control posterior prácticamente.

30 Suprimidas las faltas por la reforma del CP mediante LO 1/2015, de 30 de marzo, hay que entender la referencia a las faltas del art. 8.1 LO 2/1986, de 23 de marzo, de Fuerzas y Cuerpos de Seguridad (cuyo párrafo II fue declarado inconstitucional por la S TC 55/1990, de 28 de marzo) hecha a los delitos leves. En cuanto a los demás delitos (menos graves, graves y más graves) cometidos por la policía, nada cambia respecto al aforamiento.Vide Marchena Gómez, M., Procesos penales contra aforados, cit., pp. 518 y 519.

31 Véanse las Sentencias del Tribunal Supremo de 4 de abril de 2001 (RA 6452); y de 5 de noviembre de 2001 (ED 40643). 
b) La segunda es de naturaleza política, y es debida a la indubitada falta de confianza en los tribunales de justicia que tienen quienes pertenecen a las escalas más altas de los poderes del Estado (y no tan altas, pues recuérdese que en España están aforados hasta los policías locales). Obsérvese además que en realidad hay muchas personalidades que no son inmunes y sin embargo están aforadas. Es irrefutable que cuando las altas autoridades, funcionarios y cargos públicos están privilegiados con el aforamiento, lo que quieren es tener la garantía de que no les va a instruir la causa cualquier jovencito o jovencita que acaba de tomar posesión como juez en un pequeño pueblo seguramente con la oposición recién aprobada, novato o novata que por cierto es el juez ordinario predeterminado por la ley, competente objetiva, funcional y territorialmente a todos los efectos imaginables de lo que ello significa de acuerdo con el art. 24.2 CE, ni a juzgar cualquier tribunal provinciano, pero por cierto también juez legal, que a saber qué motivaciones ocultas pueden tener sus miembros en su contra. No, todos al Tribunal Supremo, y algunos al Tribunal Superior de Justicia de su comunidad autónoma. De manera que ningún poderoso quiere para sí la misma justicia que él mismo probablemente ha contribuido a crear y a hacer practicar para el pueblo llano. Si eso no es vulneración del principio de igualdad procesal, ¿qué es entonces la igualdad procesal? Y lo peor es que gozan de un buen apoyo doctrinal que disfraza el fondo verdadero de la cuestión con la falacia de que en realidad no son ellos los protegidos, sino las instituciones que representan, que no pueden funcionar sin su concurso, ¿tan excelso trabajo realizan o tan trascendente es socialmente su labor? Incluso ellos mismos han establecido una prohibición de renuncia al fuero (a la inmunidad), no prevista por la ley, se supone ante lo inusual de esta medida para que nadie se salga de honrado, única posibilidad de guardar subjetivamente el decoro que quedaría mientras no cambiara legalmente la situación.

c) La tercera es de naturaleza jurídica, puesto que con el aforamiento se dotan de competencias procesales determinados tribunales que en caso contrario no tendrían justificada su existencia. Si la competencia para enjuiciar a los altos cargos, autoridades y funcionarios públicos de la comunidad autonóma no se hubiera atribuido a la Sala de lo Civil y Penal del Tribunal Superior de Justicia de la Comunidad Autónoma, estos órganos jurisdiccionales, 17 nada menos en todo el país, no se podrían haber justificado cuando se crearon, porque, ¿qué habrían hecho entonces en el ámbito penal? El aforamiento sirve, pues, para dar trabajo. Pero también jurídicamente implica esta institución algo muy serio cuando se contempla el Tribunal Supremo, ya que su extensísima competencia para conocer de causas contra aforados le aleja y mucho de lo que debe ser la esencia de su alta función, el núcleo central de su 
existencia, la formación de la jurisprudencia, algo imposible de conseguir técnicamente cuando conoce en única instancia y no parte de al menos una sentencia previa que le haya fijado los hechos y los resultados probatorios obtenidos. Afirmar que a pesar de ello se cumple con el art. 14 del Pacto Internacional de Derechos Civiles y Políticos de 1966 en los casos de aforados, es ignorar por qué nació en la Francia revolucionaria la Cour de Cassation y para qué debe servir un tribunal supremo, al menos en la actualidad.

d) La cuarta razón, finalmente, es puramente pragmática y gira en torno a lo que se dice que es un efecto beneficioso que puede tener el aforamiento, pues se afirma que sirve para evitar conflictos innecesarios dentro de las instituciones en las que prestan servicios los aforados, y también de naturaleza interinstitucional. Cuando una gran variedad de altos cargos, autoridades y funcionarios públicos están protegidos por el aforamiento, como ocurre en España, piensan en el fondo los favorecidos por él, al desarrollar las tareas propias del cargo, que son totalmente libres para realizarlas, pues a pesar de la doctrina del Tribunal Constitucional en ciertos casos, el control de su labor diaria prácticamente no existe, porque para ser llevados por un acto suyo ante el Tribunal Supremo tiene que estar muy claro el hecho punible, lo que les da una gran independencia para trabajar y ello garantiza el normal funcionamiento de la institución, sin problemas, sin conflictos, dotándose de una autoestima y de una autoconfianza asombrosas, porque se sienten verdaderamente importantes, y es sabido que los que son grandes no suelen sufrir los problemas diarios de los demás. La repercusión externa de ello es enorme, hasta tal punto que entre nosotros está más que extendida y consolidada la idea de que una autoridad es importante sólo si está aforada, y si no está aforada es porque es un político de ínfima categoría. Por eso hay tantos aforamientos profesionales, además de los políticos, que no son pocos tampoco. Qué explicación dar si no a que en España estén aforados los jueces de primera instancia, los titulares y los suplentes, ¿que realizan una función de trascendencia social sin precedentes? ¿Nos conformamos con este paupérrimo razonamiento? Si así fuera, todos los jueces, suplentes o no, norteamericanos, ingleses, alemanes, italianos, franceses y portugueses, por centrarnos en los países que importan jurídicamente a la doctrina española, estarían aforados, y no hay ni uno sólo, salvo en un caso en Alemania pero que en realidad no es aforamiento, en donde le puede costar al juez su pan, no la cárcel. Esto es sencillamente una burla al sistema de justicia español, porque no se quiere aplicar al poderoso la misma norma prevista para el pueblo llano.

Estos argumentos no pueden ser considerados irreales, desmesurados o que sustentan posiciones absolutamente inasumibles o impracticables, con mucha 
mayor razón en ningún caso pueden tildarse de radicales o extremistas ${ }^{32}$. El Derecho comparado demuestra, correctamente entendido y trasladado, que es posible limitar los aforamientos como mucho a uno, todo lo más a dos: El Jefe del Estado y el Presidente del Gobierno, y nadie más. Cierto es que para que ello fuera posible en España habría que reformar la Constitución, pero si no se reformara y se suprimieran todos los demás aforamientos que no se regulan en ella, quedarían reducidos a tres instituciones constitucionales: El Presidente del Gobierno, los Ministros del Gobierno y los parlamentarios estatales (diputados y senadores), es decir, como mucho a 600 personalidades. Sin reformar la Constitución no habría ninguno más, y ya sería haber progresado mucho, aunque todavía quedaríamos muy lejos de los países citados.

¿Por qué es posible que Italia y Portugal sólo contemplen un aforamiento, el de sus respectivos Presidentes de la República, que en Francia sólo estén aforados el Primer Ministro y los miembros de su Gobierno, que en USA no haya ni un solo aforamiento?, ¿A qué se debe que en Alemania ni siquiera esté aforado en realidad el Bundespräsident, cómo hemos llegado en España contraria y sorprendentemente a tener cientos de miles? Si lo pensamos con seriedad, las altas instituciones constitucionales funcionan perfectamente en esos países sin el aforamiento, privilegio personal, y nunca institucional, no sólo porque lo consideran inasumible y así explicitan sus constituciones, como la nuestra, una fe ciega en la igualdad como valor superior del ordenamiento jurídico, sino también porque la practican, lo que los españoles no queremos, no sabemos o no podemos hacer.

Por eso los aforamientos, salvo los previstos en la Constitución, son inconstitucionales todos ellos sin excepción; por eso dando un paso más allá habría que reformar la Constitución y dejar sólo el del Rey, con matices, y el del Presidente del Gobierno, éste sin precisión alguna. Ejercer sin trabas la Jefatura del Estado y la Jefatura del Gobierno pueden ser en nuestra mentalidad razones poderosas para dispensar esta protección.

La lamentable situación española respecto a estos problemas debe cambiar por tanto ahora mismo si es posible, en aras de un verdadero entendimiento del principio de igualdad procesal, mucho más democrático y progresista que el que ahora tenemos. El ejemplo alemán, que causa sorpresa por su sencillez, es absolutamente válido para mostrar las consecuencias prácticas que se esperan de normas así, y que huye de cualquier tratamiento desigual, salvo en aquellos casos en donde no optar por una solución contraria podría llevar a una auténtica desestabilización democrática. Si el cambio no se produce, el sentimiento de los ciudadanos españoles de que en su país el poder es impune, y de que la igualdad, de existir, solamente se aplica a los mediocres y a los insignificantes, crecerá tanto

32 Véanse De Urbano Castrillo, E. / Dolz Lago, M.J., La cara y la cruz: Aforados, Actualidad Jurídica Aranzadi, n. ${ }^{\circ} 885,2014$, p. 2. 
que llevará al convencimiento indubitado y generalizado de que el Estado de Derecho está por esta causa en verdadero peligro.

\section{CONCLUSIONES AL HILO DE LAS ANUNCIADAS REFORMAS: ESCEPTICISMO SIN MATICES}

Hasta aquí una exposición sobre la situación jurídica del aforamiento en España, ubicado dogmáticamente entre los privilegios procesales de las altas autoridades, funcionarios y cargos públicos. Todo estaba muy tranquilo, es decir, todos los beneficiados defendían a capa y espada su privilegio, negando que lo fuera con amparo en una doctrina del Tribunal Constitucional ambigua, equivocada y enormemente anticuada, hasta que un partido político presentó en 2013 en la Mesa del Congreso de los Diputados una Proposición no de Ley relativa a la supresión de los privilegios de inviolabilidad, inmunidad y aforamiento de los políticos y otros cargos públicos ${ }^{33}$.

La iniciativa no salió adelante, pero dejó una huella social importante, porque desde entonces se empezó a hablar públicamente, particularmente en la prensa, del aforamiento como privilegio personal de unos pocos elegidos y notables y las cosas empezaron a cambiar, sobre todo cuando se constató que el aforamiento no existía en los países que tomamos siempre como modelo y que era además innecesario. Esa discusión continúa hoy, pero los propios partidos políticos se han encargado de minimizarla, puesto que al ser los diputados y senadores elegidos, que forman parte de sus candidaturas, los principales beneficiados por el aforamiento, difícilmente van a acabar con él.

Por eso han propuesto, sorprendentemente, que se ponga fin al aforamiento de quienes no están especialmente protegidos por la Constitución, es decir, principalmente, el de los jueces, magistrados y fiscales. Una propuesta no muy inteligente, pues han conseguido enfadar precisamente a quienes tienen que aplicarlo, por cierto, tampoco dispuestos a renunciar a él, lo cual nos hace ver que el problema no reside sólo en nuestra clase política, sino también en nuestras otras clases dirigentes, nada dispuestas en realidad a cambiar la situación.

Estando en pleno debate jurídico y social sobre el tema renunció a la Corona el Rey Juan Carlos. La reacción gubernamental inmediata una vez se produjo la sucesión en la Jefatura del Estado a favor del actual Rey Felipe VI fue aforar al Rey Juan Carlos, su esposa la Reina Sofía, a la actual Reina Letizia y a Doña Leonor Princesa de Asturias, así como en su caso a sus consortes, no sólo en lo penal, sino también en lo civil ${ }^{34}$, ante las Salas de lo Penal y de lo Civil del Tribunal

33 Para su debate en el Pleno, el día 7 de mayo de 2013, texto que se debatió en el Pleno el día 12 de junio de 2013 (Diario de Sesiones n. ${ }^{\circ} 119$, pp. 37 a 44).

34 A pesar de que el aforamiento en lo civil es inconstitucional por violar el principio de igualdad según la Sentencia del Tribunal Constitucional 9/1990, de 18 de enero. 
Supremo (art. 55 bis LOPJ, introducido por la LO 4/2014, de 11 de julio). La razón oculta, obvia para los promotores de la reforma, era que si estaban aforados en España más de 250.000 altas autoridades, funcionarios y cargos públicos, cómo no lo iba a estar el Rey abdicante y su familia más directa; la razón técnica, ésta explicitada, fue que al abdicar el Rey había perdido su inviolabilidad.

Como se observa, la cuestión no está ni mucho menos cerrada a favor de la supresión de los aforamientos, lamentablemente. Más bien diríamos que aprovechando la delicada cuestión política actual, parece que esté dormida, aunque algún intento ha habido de remover el tema ${ }^{35}$.

Por tanto, se puede seguir afirmando que la supresión de los aforamientos no acaba de cuajar, sigue en realidad latente, dormida como decíamos. Pero un día despertará de verdad porque todos los partidos políticos que han obtenido representación parlamentaria en las dos elecciones generales que hemos tenido, hasta ahora, el 20 de diciembre de 2015 y el 26 de junio de 2016, han llevado en sus programas la supresión de los aforamientos, con matices entre ellos, lo que me permite suponer que la seguirán llevando en el futuro mientras esté vigente. Un día u otro habrá que coger el toro por los cuernos y afrontar definitivamente la solución de este problema, una violación del principio constitucional de igualdad, tema nada baladí por tanto.

En este sentido, la situación va a pasar seguro por tener que optar por alguna de las siguientes posibilidades:

1. Realizar una reforma radical, lo que implica reformar la Constitución y perder diputados y senadores el aforamiento.

2. Apostar por una reforma moderada, más suave, eliminando todos los aforamientos que no están previstos en la Constitución, con dos variantes:

a) Incluyendo a los jueces, magistrados y fiscales.

b) Excluyéndolos.

Como una reforma de la Constitución sólo por este tema no es posible en estos momentos, y quizás en algún tiempo tampoco, ya que se aprovecharía para reformar otras muchas cosas, entre otras el modelo de Estado de las autonomías que actualmente tenemos, dada la gran crisis por la «cuestión catalana» que existe en estos momentos en España, la primera opción parece hoy descartada.

La segunda es más viable, pero cuenta con la segura oposición de jueces, magistrados y fiscales, tal y como se demostró frente al proyecto, non nato, de

35 Hubo una iniciativa en el Senado para suprimir los aforamientos de los cargos políticos que implicaba reformar la Constitución, fechada el 29 de marzo de 2016, lo cual era muy difícil de conseguir con un Gobierno en funciones. No salió adelante. Otro partido presentó al día siguiente como alternativa una propuesta de nombramiento de una ponencia ad hoc para que estudiase con calma el tema. La convocatoria de nuevas elecciones para junio de 2016 impidió su constitución. 
nueva Ley Orgánica del Poder Judicial de 2014, que los suprimía todos, pues calificaron la idea del Gobierno de «sinvergonzonería» porque restaba credibilidad a las instituciones que representan ${ }^{36}$, entendiendo las asociaciones de jueces que el aforamiento es una garantía para los ciudadanos ${ }^{37}$, e incluso el propio Fiscal General vio "poco meditada» esa decisión ${ }^{38}$. Aunque sólo tres meses antes el Presidente del Tribunal Supremo y del Consejo General del Poder Judicial opinaba que los jueces no debían tener aforamiento o tenerlo limitado ${ }^{39}$. Por ello, si al final se opta por la opción segunda b), habremos hecho de nuevo el ridículo, pues todavía quedarían unos 10.000 aforamientos en España y, sobre todo, ahondaríamos todavía más si cabe en la desconfianza de la ciudadanía, que visionaría muy claramente que el poderoso no desea perder sus privilegios, importándole poco o nada tamaña violación del principio de igualdad. La Justicia para el pueblo seguiría siendo distinta, por tanto, de peor calidad y tan lenta, cara e impredecible como demuestra día a día que lo es.

No debería descartarse volver al antejuicio, regulado mucho mejor y adaptado a la realidad actual, para resolver el problema de los magistrados, jueces y fiscales una vez se suprima su aforamiento ${ }^{40}$. La Ley del Jurado de 1995 erró al suprimirlo ${ }^{41}$, pero ésta es otra cuestión, que no debe ser tratada aquí.

De ahí mi enorme escepticismo, sin matices, ante el futuro que le espera a la institución. En mi opinión, para finalizar, o se reforma la Constitución y se dejan sólo el del Rey y el del Presidente del Gobierno, o en España no hay nada que hacer, seguiremos con más de 250.000 , o en su caso 10.000 , privilegiados injustamente, porque son tratados desigualmente respecto a un ciudadano normal. Soy partidario por tanto en este tema de una reforma radical, como merece ser el respeto al principio de igualdad, directo, frontal, sin excepciones, igualmente radical en definitiva.

Title: Unconstitutional and Unnecessary Procedural Privileges in the Democratic Spain of the 21st Century: the Surprising Maintenance of the Institution of "Aforamiento»

ABSTRACT: Spain contemplates an additional measure of immunity for high authorities, civil servants and public officers, which consists on being tried by a court that is superior to the legal ordinary one, in case

36 V. Diario del Derecho Iustel Actualidad, 8 de septiembre de 2014.

37 V. Diario del Derecho Iustel Actualidad, 2 de julio de 2014.

38 V. Diario del Derecho Iustel Actualidad, 15 de septiembre de 2014.

39 V. Diario del Derecho Iustel Actualidad, 16 de junio de 2014.

40 La bibliografía sobre el extinto antejuicio es inmensa. Baste por todos la cita de ZarZALEJOs NiETo, J., Proceso penal contra jueces y magistrados, La especialidad del antejuicio, Ministerio de Justicia-Universidad Complutense, Madrid 1992.

41 Su DA-1. ${ }^{a}$ suprimió el antejuicio para exigir responsabilidad criminal a jueces y magistrados, derogando el art. 410 de la Ley Orgánica del Poder Judicial, y los arts. 757 a 778 de la Ley de Enjuiciamiento Criminal. 
that they have committed a felony. This figure, known as "aforamiento», is practically inexistent in the western legal culture to which our country belongs. Furthermore, its extension is shameful, since more than 250.000 high authorities, civil servants and public offccers benefit from this privilege, making it indefensible before normal citizens. It is also unconstitutional for the reasons we explain in this paper, because it represents a privilege that is contrary to the principle of equality before the law. This study proposes a drastic reduction, maintaining the privilege for a maximum of two constitutional figures, the head of state and the head of government, a purpose that evidently requires a constitutional reform.

RESUMEN: España contempla una medida de inmunidad adicional para altas autoridades, funcionarios y cargos públicos consistente en el conocimiento por un tribunal superior al ordinario legal de las causas contra ellos en caso de haber cometido delito, llamada aforamiento, que es prácticamente inexistente en el mundo jurídico occidental al que nuestro país pertenece. Además, su extensión es vergonzosa, pues están aforadas más de 250.000 autoridades, funcionarios y cargos públicos, lo que la hace indefendible ante el ciudadano normal. Es además inconstitucional, por las razones que explicamos en el texto, ya que representa un privilegio vulnerador del principio de igualdad. En este articulo se propone su drástica reducción, dejando aforadas como máximo a dos figuras constitucionales, el Jefe del Estado y el Jefe del Gobierno, para lo que evidentemente bay que reformar la Constitución.

KEY WORDS: Criminal procedure, procedural privileges, parliamentarians, venue.

Palabras Clave: Proceso penal, privilegios procesales, diputados y senadores, aforamientos.

FECHA DE RECEPCIÓN: 20.06.2016

FECHA DE ACEPTACIÓN: 27.07.2016 
